\title{
Risk Assessment of Triclosan, a Cosmetic Preservative
}

\author{
Jung Dae Lee', Joo Young Lee ${ }^{2}$, Seung Jun Kwack ${ }^{3}$, Chan Young Shin ${ }^{4}$, Hyun-Jun Jang ${ }^{5}$, \\ Hyang Yeon Kim ${ }^{5}$, Min Kook Kim ${ }^{1}$, Dong-Wan Seo ${ }^{5}$, Byung-Mu Lee ${ }^{1}$ and Kyu-Bong Kim ${ }^{5}$ \\ ${ }^{1}$ College of Pharmacy, Sungkyunkwan University, Suwon, Korea \\ ${ }^{2}$ College of Pharmacy, The Catholic University of Korea, Bucheon, Korea \\ ${ }^{3}$ Department of Bio Health Science, Changwon National University, Changwan, Korea \\ ${ }^{4}$ Department of Neuroscience, School of Medicine and Center for Neuroscience Research, Konkuk University, Seoul, \\ Korea \\ ${ }^{5}$ College of Pharmacy, Dankook University, Cheonan, Korea
}

\begin{abstract}
Triclosan (TCS) is an antimicrobial compound used in consumer products. The purpose of current study was to examine toxicology and risk assessment of TCS based on available data. Acute toxicities of oral, transdermal and inhalation routes were low, and phototoxicity and neurotoxicity were not observed. Topical treatment of TCS to animal caused mild irritation. TCS did not induce reproductive and developmental toxicity in rodents. In addition, genotoxicity was not considered based on in vitro and in vivo tests of TCS. It is not classified as a carcinogen in international authorities such as International Agency for Research on Cancer (IARC). No-observed-adverseeffect level (NOAEL) was determined $12 \mathrm{mg} / \mathrm{kg}$ bw/day for TCS, based on haematoxicity and reduction of absolute and relative spleen weights in a 104-week oral toxicity study in rats. Percutaneous absorption rate was set as $14 \%$, which was human skin absorption study reported by National Industrial Chemicals Notification and Assessment Scheme (NICNAS) (2009). The systemic exposure dosage (SED) of TCS has been derived by two scenarios depending on the cosmetics usage of Koreans. The first scenario is the combined use of representative cosmetics and oral care products. The second scenario is the combined use of rinse-off products of cleansing, deodorants, coloring products, and oral care products. SEDs have been calculated as $0.14337 \mathrm{mg} / \mathrm{kg}$ bw/day for the first scenario and $0.04733 \mathrm{mg} / \mathrm{kg}$ bw/day for the second scenario. As a result, margin of safety (MOS) for the first and second scenarios was estimated to 84 and 253.5, respectively. Based on these results, exposure of TCS contained in rinse-off products, deodorants, and coloring products would not pose a significant health risk when it is used up to $0.3 \%$.
\end{abstract}

Key words: Triclosan, Cosmetic ingredients, Risk assessment, Rinse-off products

\section{Correspondence to: Kyu-Bong Kim, Department of Pharmacy, College of Pharmacy, Dankook University, 119 Dandae-ro, Cheonan, Chungnam 31116, Korea \\ E-mail: kyubong@dankook.ac.kr}

This is an Open-Access article distributed under the terms of the Creative Commons Attribution Non-Commercial License (http:// creativecommons.org/licenses/by-nc/3.0) which permits unrestricted non-commercial use, distribution, and reproduction in any medium, provided the original work is properly cited.

List of Abbreviations: ALP, Alkaline phosphatase; ALT, Alanine aminotransferase; AST, Aspartate aminotransferase; BUN, Blood urea nitrogen; $\mathrm{CHO}-\mathrm{K} 1-\mathrm{BH} 4$, Chinese hamster ovary; EFSA, European Food Safety Authority; EPA, Enviromental Protection Agency; FDA, Food and Drug Administration; FSH, Follicle-stimu- lating hormone; $\mathrm{HC}$, Health Canada; IARC, International Agency for Research on Cancer; KoNEHS, Second Korean National Environmental Health Survey; LH, Luteinizing hormone; LOAEL, Lowest-observed-adverse-effect level; MFDS, Ministry of Food and Drug Safety; MOS, Margin of safety; NICNAS, National Industrial Chemicals Notification and Assessment Scheme; NOAEL, Noobserved-adverse-effect level; OECD, Organization for Economic Cooperation and Development; ORs, Odds ratios; PCV, Packed cell volumes; RBC, Red blood cell; SCCP, Scientific Committee on Consumer Products of the European Commission's DirectorateGeneral for Health and Consumer Protection; SCCS, Scientific Committee on Consumer Safety; SCF, Scientific Committee on Food; SED, Systemic exposure dosage; SLS, Sodium laurylsulfate; T4, thyroxine; TCS, Triclosan; WBC, White blood cell. 


\section{INTRODUCTION}

Triclosan (TCS, 5-chloro-2-(2,4-dichlorophenoxy)phenol) (CAS RN 3380-34-5) is an antibacterial and antifungal agent present in many consumer products. It is used in many personal hygiene products including toothpastes, antibacterial soaps (bar and liquid), deodorants (bar and liquid), and cosmetics $(1,2)$. TCS is also known and sold as commercial names of Irgasan, DP300, FAT 80'023, CH 3565 and GP 41-353 (3).

In Europe, the maximum allowable concentration of TCS in cosmetics and mouthwashes is $0.3 \%$. In Japan, the maximum allowable concentration of TCS in cosmetics is $0.1 \%$, and in Norway a maximum allowable limit is not specified (2). In the USA, the maximum allowable concentration of TCS is $0.3 \%$ in soap and deodorant (2).

TCS was found in human urine, plasma and breast milk during a biomonitoring study (4-7), but it was quickly eliminated primarily in the urine with a mean excretion half-life of $11 \mathrm{hr}$, with no accumulation (5-12). A study by Park et al. (13) reported that the concentration of TCS in urine increases with the frequency of use of personal care products in Korea. Despite a short half-life, serious concerns have been raised regarding the toxicity of TCS.

TCS in toothpaste, soap, and cosmetics may accumulate in the body, which could have an adverse effect on thyroid hormones and genitalia, and increase the risk of developing breast cancer. Animal studies have shown that TCS adversely affects endocrine function, thyroid hormone homeostasis, and antibiotic resistance (14-19). In Health Canada (HC) (20), overall toxicological database survey showed that TCS ingestion induced liver toxicity in rodents and dogs, and mice were the most sensitive species to TCS toxicity. According to the HC report, rodentspecific metabolism of TCS resulted in a modest decrease in serum thyroxine (T4) levels in rats due to target organ (liver) damage. However, HC reported that humans were not significantly at risk because of an ability to adapt to changes in T4 levels than rodents. Another study that evaluated TCS toxicity during pregnancy or at birth using anthropometric measurements concluded that TCS in cleansing products (mainly liquid and bar soaps) did not affect thyroid function in humans (21). Rat, mouse, and hamster studies showed that TCS can cause liver pathogenesis and tumor formation in mice, but not in rats or hamsters (22). However, several in vitro and in vivo studies have reported inconsistent results regarding the effects of TCS in humans. Due to concerns over the wide range of sources of human exposure and potential adverse health effects, interest in TCS research has increased sharply.

In this review, we performed a comprehensive toxicity and risk assessment of TCS with specific focus on route of exposure (skin, mouth, and inhalation) and various product types (rinse-off and leave-on products). We used a typ-
Table 1. Physical and chemical properties of triclosan

\begin{tabular}{ll}
\hline \hline \multicolumn{1}{c}{ Property } & \multicolumn{1}{c}{ Value and conditions } \\
\hline INCI name & Triclosan \\
IUPAC name & 5-Chloro-2-(2,4-dichlorophenoxy)phenol \\
CAS No. & $3380-34-5$ \\
Molecular formula & $\mathrm{C}_{12} \mathrm{H}_{7} \mathrm{Cl}_{3} \mathrm{O}_{2}$ \\
Molar mass & $289.54 \mathrm{~g} / \mathrm{mol}$ \\
Chemical structure
\end{tabular}

ical Korean exposure algorithm and exposure data to estimate daily exposure to TCS from cosmetic products (23). The margin of safety (MOS) was determined by applying an appropriate toxicity reference value based on this systemic exposure dose.

Physicochemical properties of triclosan. 5-Chloro2-(2,4-dichlorophenoxy)phenol (IUPAC name), commonly known as TCS, is a chlorinated aromatic compound with both phenolic and ether structural moieties. TCS is a white crystalline powder and possesses high chemical stability. The CAS number of TCS is 3380-34-5. The molecular weight of TCS is $289.54 \mathrm{~g} / \mathrm{mol}$, the $\log$ Pow is 4.76 , and the melting and boiling points are $55-57^{\circ} \mathrm{C}, 280-290^{\circ} \mathrm{C}$, respectively. Physical and chemical properties are summarized in Table 1.

Cosmetic use and regulation. TCS is an antimicrobial compound that has been used in consumer products for about 40 years. It is widely used in personal care products as a non-ionic antimicrobial agent in products such as bar and liquid soap, deodorants, skin care products, foot care products, oral care products, and make-up products (3). TCS has also been evaluated by the Scientific Committee on Food (SCF) (24) and the European Food Safety Authority (EFSA) (25) for safe use in food contact materials and was given a $5 \mathrm{mg} / \mathrm{kg}$ food restriction limit in SCF_List 3 (24). The category with the highest content of TCS-containing products is personal hygiene products (226 TCS-containing products, 162 of which are deodorant products) (2). Cosmetic products that contain TCS were reported to the Ministry of Food and Drug Safety (MFDS) by domestic manufacturers in 2015 (26). One 
Table 2. Triclosan regulations of cosmetics in various countries

\begin{tabular}{|c|c|c|c|c|}
\hline Usage & Korea & Europe & Japan & USA \\
\hline \multirow{2}{*}{$\begin{array}{l}\text { Sterilization and } \\
\text { Preservative }\end{array}$} & \multirow{2}{*}{$\begin{array}{l}\text { Rinse-off: body cleansing products, } \\
\text { Deodorant (excluding spray products), } \\
\text { Used locally: foundation to hide } \\
\text { skin defects (ex. blemish concealers) } \\
\leq 0.3 \%\end{array}$} & $\begin{array}{l}\text { Body soap, hand soap, shower gel, } \\
\text { deodorant, pate powder, blemish } \\
\text { concealer } \leq 0.3 \%\end{array}$ & \multirow[t]{2}{*}{$\leq 0.1 \%$} & \multirow{2}{*}{$\begin{array}{l}\text { Soap and } \\
\text { deodorant } \\
\leq 0.3 \%\end{array}$} \\
\hline & & $\begin{array}{l}\text { Toothpaste } \leq 0.3 \% \\
\text { Mouthwash } \leq 0.2 \%\end{array}$ & & \\
\hline
\end{tabular}

Table 3. Summary of acute toxicity of triclosan

\begin{tabular}{llccc}
\hline \hline Route & Species & Dose & Results & Ref. \\
\hline Oral & Rat & $5,000 \mathrm{mg} / \mathrm{kg} \mathrm{bw} /$ day & $\mathrm{LD}_{50}>5000$ \\
\hline Inhalation & Rat & $0.123,0.466,0.513,0.678 \mathrm{mg} / \mathrm{L}$ air/day & $\mathrm{LC}_{50}$ \\
\hline \multirow{2}{*}{ Dermal } & Rabbit & $0,1,000,6,000 \mathrm{mg} / \mathrm{kg} \mathrm{bw} /$ day & Male 0.286, female 0.603 & 27 \\
\hline
\end{tabular}

$\mathrm{LD}_{50}, 50 \%$ lethal dose.

hundred twenty-seven of 100,190 cosmetics in Korea contained TCS, and TCS was mainly used in rinse-off products such as body cleansers and foam cleansers (23). TCS is used as a sterilizing and preserving agent in cosmetics in Korea and Europe. In some product types, such as rinse-off products, the maximum allowable TCS content is $0.3 \%$. In Japan, the maximum allowable TCS content is $0.1 \%$. In the United States, the maximum allowable concentration of TCS is $0.3 \%$ in soap and deodorant. Table 2 shows the standards for management of TCS in cosmetics in each country.

\section{HAZARD IDENTIFICATION}

Single-dose toxicity. TCS has exhibited low toxicity in acute studies. TCS is not acutely toxic via the oral route of administration, with a high oral $\mathrm{LD}_{50}$ value of greater than $5,000 \mathrm{mg} / \mathrm{kg}$ bw/day in rats. Clinical manifestations were observed in all animal species evaluated, including diarrhea, soft feces, ano-genital staining, hunched posture, lethargy, abdominal distension, piloerection, ocular discharge, and/or irregular respiration in response to 5,000 $\mathrm{mg} / \mathrm{kg}$ bw/day of TCS (27). The rabbit dermal $\mathrm{LD}_{50}$ value for TCS was greater than $6,000 \mathrm{mg} / \mathrm{kg}$ bw. One male rabbit treated dermally with $6,000 \mathrm{mg} / \mathrm{kg}$ bw died after 8 days. Sedation, dyspnoea, exophthalmos, wrinkled fur and hunched posture were observed in response to 1,000 and $6,000 \mathrm{mg} / \mathrm{kg}$ of TCS (27). An inhalation study evaluated clinical symptoms and mortality in rats after inhalation of TCS in aerosol form for $4 \mathrm{hr}$. During exposure, dyspnea, exophthalmos, ruffled fur, curved body position and cyanosis developed in some animals. The $\mathrm{LC}_{50}$ for TCS was $0.286 \mathrm{mg} / \mathrm{L}$ air in males and $0.603 \mathrm{mg} / \mathrm{L}$ air in females (27). Acute toxicity of TCS according to routes of admin- istration is summarized in Table 3 .

Repeated dose toxicity. TCS dissolved in acetone or propylene glycol vehicle was administered to a $2 \times 3 \mathrm{~cm}^{2}$ section of dorsal skin on mice ( $25 \mathrm{~g})$ at doses of 12,24 , 60,120 , and $240 \mathrm{mg} / \mathrm{kg}$ bw/day (TCS concentrations: 0.3 , $0.6,1.5,3$, and $6 \%$; dosing volume, $0.1 \mathrm{~mL}$ ). When TCS was dissolved in propylene glycol, skin irritation and keratinizing symptoms were observed in response to $1.5 \mathrm{mg}$ / animal/day ( $60 \mathrm{mg} / \mathrm{kg}$ bw/day) of TCS. When dissolved in acetone, symptoms appeared at $3.0 \mathrm{mg} /$ animal/day. Symptoms such as liver weight gain accompanied by centrilobular hypertrophy were observed in animals treated with TCS at greater than $1.5 \mathrm{mg} / \mathrm{animal} /$ day $(\geq 60 \mathrm{mg} / \mathrm{kg} \mathrm{bw} /$ day). The NOAEL value in this study was $24 \mathrm{mg} / \mathrm{kg}$ bw/ day (28-29). In a similar study, the NOAEL value in rats was $3.0 \mathrm{mg} /$ animal/day (12 $\mathrm{mg} / \mathrm{kg}$ bw/day), which was based on skin irritation observed at $6.0 \mathrm{mg} / \mathrm{animal} /$ day (30).

In a study by Leutkemeier et al. (31), deaths were observed when TCS was administered by inhalation at concentrations of $50-1,300 \mathrm{mg} / \mathrm{m}^{3}$ on the first day. At the deceased concentration, the dose was lowered on day $2(0$, 50,115 , or $\left.301 \mathrm{mg} / \mathrm{m}^{3}\right)$. TCS was dosed for 15 days. The dead animals exhibited bleeding and inflammatory changes in their mucosa. Dose-dependent changes in enzyme activities such as glutamic-pyruvic transaminase and alkaline phosphatase were observed. The NOAEL value for inhalation of TCS was $50 \mathrm{mg} / \mathrm{m}^{3}$, which corresponded to the lowest concentration tested.

TCS with a purity of $99 \%$ or greater was fed to male and female MAGf (SPF) mice at doses of 50 and 1,000 ppm (male: $6.48 \mathrm{mg} / \mathrm{kg} /$ day, $113 \mathrm{mg} / \mathrm{kg} /$ day, female: 8.25 $\mathrm{mg} / \mathrm{kg} /$ day, $169 \mathrm{mg} / \mathrm{kg} /$ day) for 28 days, followed by a 14 
day recovery period. No deaths were observed, and there were no significant differences in weight change and food intake in the group administered TCS compared with the control group. In the $50 \mathrm{ppm}$ dose group, alanine aminotransferase (ALT) and aspartate aminotransferase (AST) activities increased in males and phosphate levels decreased in females. Red blood cell (RBC) count, hemoglobin, hematocrit and mean erythrocyte pigment decreased in both the male and female groups, but the number of platelets increased. Red blood cell count, hemoglobin, hematocrit, and erythrocyte pigment decreased in males and females in the $1,000 \mathrm{ppm}$ dose group, but the number of platelets increased. In addition, activity of alkaline phosphatase (ALP), AST, and ALT increased 2-3 fold. Blood urea increased in males and females, but creatinine levels were higher in females. Plasma phosphates in females were low (only females were measured). After the recovery period, plasma creatinine (high-dose females) and urea (high-dose animals) levels did not normalize, ALT normalized in both males and females, and AST activity normalized only in males. In addition, liver weights in male and female mice treated with 1,000 ppm TCS increased significantly by 70 $80 \%$ but returned to normal by the end of the recovery period. The mean kidney weight in males was lower than that of the control group at the end of administration of TCS. Decreased kidney weight was observed, but there were no differences in macroscopic examination. Liver hypertrophy and cell necrosis were observed. Necrosis and Kupffer cells were observed in the 1,000 ppm dose group in hepatocytes of both males and females. Polymorphonuclear leukocytes were observed in the renal outer medulla in two out of five females. Therefore, the NOAEL in male and female mice was $50 \mathrm{ppm}$, and the LOAEL was $1,000 \mathrm{ppm}$ because of hepatic alteration $(3,32)$.

CD-1 mice (15/sex/group) were treated for 13 weeks with repeated oral TCS doses of $0,25,75,200,350,750$, and $900 \mathrm{mg} / \mathrm{kg}$ bw/day in food. At $25 \mathrm{mg} / \mathrm{kg}$ bw/day and $200 \mathrm{mg} / \mathrm{kg}$ bw/day, increased ALP was observed in males and females, respectively. Other changes included decreased total cholesterol greater than $25 \mathrm{mg} / \mathrm{kg}$ bw/day in all animals and elevated ALT levels (males at $350 \mathrm{mg} / \mathrm{kg}$ body weight/day and above, females at $750 \mathrm{mg} / \mathrm{kg}$ body weight/ day and above). The NOAEL could not be determined in this study because of treatment-related elevation in ALP and cholesterol at the lowest dose (these effects may have occurred at doses below $25 \mathrm{mg} / \mathrm{kg}$ bw/day) (33).

Sprague-Dawley (S-D) rats were given TCS with food at doses of $0,100,300$, and $600 \mathrm{mg} / \mathrm{kg}$ bw/day for 13 weeks. RBC count, hematocrit, and hemoglobin was significant decreased in response to $600 \mathrm{mg} / \mathrm{kg} /$ day of TCS in females. In males, RBC count was significant decreased in response to $300 \mathrm{mg} / \mathrm{kg} /$ day of TCS. However, it was reported to be within normal ranges. In addition, at $600 \mathrm{mg} / \mathrm{kg} /$ day, significant increase in relative liver weights was seen in males and females. Relative weights of spleen increased and relative kidney weights in males and females decreased in response to $300,600 \mathrm{mg} / \mathrm{kg} /$ day of TCS. Although statistically significant decrease in cholesterol was observed in $100 \mathrm{mg} / \mathrm{kg} /$ day dose group, this was in males only. Therefore, the NOAEL was estimated at approximately $100 \mathrm{mg} / \mathrm{kg}$ bw/day, which was based on histopathological changes in the liver $(34,35)$.

Syrian hamsters were given TCS with food at doses of $0,75,200,350,750,900 \mathrm{mg} / \mathrm{kg}$ bw/day for 13 weeks. No mortality or clinical signs were observed. Food intake was increased at 7, 8, 12 and 13 weeks in males in response to 750 and $900 \mathrm{mg} / \mathrm{kg}$ bw/day. In females, food intake was increased at 6,7,12 and 13 weeks in response to $900 \mathrm{mg} /$ $\mathrm{kg}$ bw/day. Water intake also increased in both sexes in response to $200-900 \mathrm{mg} / \mathrm{kg}$ bw/day compared with that of the control group. Water intake increased by $30 \%$ in 200 $\mathrm{mg} / \mathrm{kg} \mathrm{bw} /$ day group, compared to the control group. Water intake increased by $170 \%$ in males that received $900 \mathrm{mg} /$ $\mathrm{kg}$ bw/day compared to the control group. TCS doses up to $350 \mathrm{mg} / \mathrm{kg}$ bw/day did not induce weight gain. However, administration of 750 and $900 \mathrm{mg} / \mathrm{kg} \mathrm{bw} /$ day, weight reduction was observed until the end of the experiment. In addition, the kidney was identified as a major target organ based on macroscopic and histopathologic abnormalities in response to 750 and $900 \mathrm{mg} / \mathrm{kg}$ bw/day of TCS, and kidney weight and relative kidney weight ratio were increased in males. Furthermore, morphological changes such as discoloration and granulation of the kidneys to yellowish brown were observed in both sexes. Renal toxicity was observed by a macroscopic examination, and the incidence and severity were increased with higher doses. Doses of 750 and $900 \mathrm{mg} / \mathrm{kg}$ bw/day might cause impaired renal function in animals. No histopathological damage was induced by TCS in the liver. However, a dose of $900 \mathrm{mg} /$ $\mathrm{kg}$ bw/day increased reticulocytes and decreased RBC count. Furthermore, histopathological analysis showed gastritis and inflammatory reactions in response to 750 and $900 \mathrm{mg} / \mathrm{kg}$ bw/day of TCS. Renal toxicity was observed in response to $350 \mathrm{mg} / \mathrm{kg}$ bw/day, but the incidence and severity were lower compared to that in response to higher doses. At $200 \mathrm{mg} / \mathrm{kg}$ bw/day, there was an increase in water intake, a decrease in urinary osmotic pressure, and a decrease in hemoglobinuria. Therefore, the NOAEL was determined to be $75 \mathrm{mg} / \mathrm{kg}$ bw/day, and the LOAEL was set at $200 \mathrm{mg} / \mathrm{kg}$ bw/day $(35,36)$.

Two rabbit studies reported conflicting results. One study $(0,12.5,25,62.5$, or $125 \mathrm{mg} / \mathrm{kg}$ bw/day, 90 days, diet $)$ concluded that TCS was harmless up to $125 \mathrm{mg} / \mathrm{kg}$ bw/ day. In contrast, the other study $(0,3,30$, or $150 \mathrm{mg} / \mathrm{kg}$ bw/day, 13 weeks, oral gavage) set the NOAEL at $3 \mathrm{mg} /$ $\mathrm{kg}$ bw/day based on pulmonary infection. However, the investigators noted that the association between lung infection with TCS was unclear $(3,37,38)$. 
TCS was fed to beagle dogs (4/sex/group) at doses of 125,313 , and $625 \mathrm{ppm}(5,12.5$, and $25 \mathrm{mg} / \mathrm{kg}$ bw/day, respectively) daily for 13 weeks. No death or behavioral abnormalities were found in response to TCS treatment, and food intake did not significantly differ from that of controls. There were no ocular lesions or hearing loss, and there were no significant hematologic difference in the TCS treatment groups compared to the control group. All other clinical signs were within the normal ranges, and there was no significant differences between the TCS treatment groups and the control groups. The NOAEL was determined to be greater than $25 \mathrm{mg} / \mathrm{kg}$ bw/day $(3,35,37)$.

In subacute and subchronic studies using Baboon monkeys, liver and lung inflammation were observed, but there were no significant differences between the control and TCS groups $(3,39)$. Symptoms including abdominal pain, and diarrhea were not observed after treatment with $30 \mathrm{mg} / \mathrm{kg} /$ day of TCS for one year. Thus, the NOAEL was determined to be $30 \mathrm{mg} / \mathrm{kg} /$ day. At a dose of $300 \mathrm{mg} / \mathrm{kg}$ bw/day, subacute, subchronic, and chronic studies showed hematologic changes dependent on the duration of TCS administration. Clinical chemistry changes were occasionally observed, but no substantial histological changes were observed $(3,40)$.

Mice were fed $0,10,30,100$ or $200 \mathrm{mg} / \mathrm{kg}$ bw/day of TCS with food for 18 months. Dose-dependent hepatotoxicity was observed and other hematologic toxicities were observed at medium and high doses. The LOAEL value was determined to be $10 \mathrm{mg} / \mathrm{kg}$ bw/day based on liver weight gain. This dose level was considered the NOAEL based on hepatotoxicity, but not liver weight gain (41).

TCS was fed to rats with food at $0,300,1,000$, and 3,000 ppm (Male: 0, 12, 40, $127 \mathrm{mg} / \mathrm{kg}$ bw/day, female: 0 , $17,56,190 \mathrm{mg} / \mathrm{kg}$ bw/day) for 104 weeks. An additional group of rats was given a toxic dose of $6,000 \mathrm{ppm}$ and then sacrificed at 52 weeks. None of the rats treated with this dose died because of TCS treatment. Body weight was significantly decreased in response to high doses in females at 52 weeks. Food intake significantly increased in response to high doses of TCS in males. Biochemical analysis showed that protein, blood urea nitrogen (BUN), glucose, bilirubin, triglyceride, and liver enzymes were altered temporarily. Hematological observations showed significant changes. Mean hemoglobin levels were increased in the middle and high dose female groups and the low dose male group. In addition, morphology changes in red blood cells were observed in males in response to high doses of TCS. Coagulation time was increased in male rats treated 3,000 ppm of TCS and white blood cell (WBC) count was decreased in female rats in response to 3,000 ppm of TCS. At 52 weeks, heart, liver, brain, kidney (male), and ovary (female) weights were decreased in response to 3,000 ppm of TCS. At 104 weeks, absolute weights of the adrenal glands were increased in response to $1,000 \mathrm{ppm}$ of
TCS, and brain weights of males were decreased response to $3,000 \mathrm{ppm}$ of TCS. Absolute and relative weights of ovaries increased and relative spleen weights in females decreased in response to 3,000 ppm of TCS, and absolute and relative spleen weights in females decreased in response to $1,000 \mathrm{ppm}$ of TCS. Hepatocyte hypertrophy and hepatocytic inclusion (hyaline-staining, and round-shaped) were significantly observed in male rats at $3,000 \mathrm{ppm}$ (13 weeks) and 6,000 ppm (52 weeks). Other histological lesions were considered unrelated to treatment. The authors estimate NOAEL to be approximately $48 \mathrm{mg} / \mathrm{kg} /$ day (male $40 \mathrm{mg}$ / $\mathrm{kg} \mathrm{bw} /$ day, female $56 \mathrm{mg} / \mathrm{kg}$ bw/day). In this study, SCCP suggested a NOAEL of $12 \mathrm{mg} / \mathrm{kg}$ bw/day based on observations of increased mean hemoglobin concentration and spleen weight reduction at $1,000 \mathrm{ppm}$ dose in female rats $(3,42)$.

Syrian hamsters were fed a diet containing TCS at doses of $12.5,75$, and $250 \mathrm{mg} / \mathrm{kg} /$ day for $90-95$ weeks. In the high dose group, the mortality rate increased after 81 weeks, and the condition of the hamsters deteriorated until the end of the experiment. Body weight gain was lower in both males and females in the high dose group. In the 75 $\mathrm{mg} / \mathrm{kg} /$ day group, body weight gain was lower from 3 to 13 weeks. Food consumption decreased for the first 3 weeks in the middle and high dose groups when compared with control group. Body weight reduction was observed in females in the middle dose group, and in all animals at the high dose. There were no differences in food intake between the treated groups and the control group after 3 weeks. Water intake was generally higher in the high dose group than in the control group. Packed cell volumes (PCV) decreased in the middle and high dose groups in females, and mean corpuscular hemoglobin concentration increased. In addition, reticulocyte counts increased in males and females in the high dose group, and platelet counts decreased in males and females in the middle and high dose groups. Hemoglobin, RBC count, and cell volume decreased, and WBC count increased in the high dose group. At 50 weeks in the high dose group, plasma urea nitrogen levels increased in both sexes and calcium concentration decreased in females. Increased levels of triglycerides in response to high dose TCS were associated with decreased plasma glutamic-pyruvate transaminase. The amount of urine was significantly increased in the high dose group regardless of male body weight. Urinary heme and RBC count increased in both males and females in the high dose group. There were no differences in weights of any other organs at autopsy. Irregular cortical scarring of the kidneys was observed in all males and females in the high dose group at 52 weeks of administration. Histopathologic examinations at 52 weeks showed renal nephropathy in all dose groups, with increased incidence and severity at high dose levels. In addition, males in the high dose group showed atypical hyperplasia in the fundic region of the 
stomach, as well as spermatozoa and germ cell effects. Distended gastric glands were observed in females in the high dose group, and benign papilloma was observed in females at all doses. In this study, LOAEL was set at 250 $\mathrm{mg} / \mathrm{kg}$ bw/day due to increased mortality, decreased weight gain, hematologic changes, and stomach lesions and NOAEL was set at $75 \mathrm{mg} / \mathrm{kg}$ bw/day $(20,35,43)$.

Male Sprague-Dawley rats (3 weeks old) were orally administered with doses of $0.25,25,250$ and $750 \mathrm{mg} / \mathrm{kg} /$ day of TCS for 60 day. Body weight, relative weights of liver, kidneys, testes, and adrenal glands were significantly decreased in response to $750 \mathrm{mg} / \mathrm{kg}$ of TCS. Serum AST, ALT activities, levels of BUN, and creatinine were significantly increased in response to $750 \mathrm{mg} / \mathrm{kg}$ of TCS. In addition, at $750 \mathrm{mg} / \mathrm{kg}$ of TCS, protein expression of hepatic CYP2B1, RXR/PPAR and malondialdehyde were increased. Histologic changes such as decreased Bowman's space, occlusion of the tubular lumen, and degeneration of tubular epithelial cells in the kidney were observed in response to $750 \mathrm{~g} / \mathrm{kg}$ of TCS (44).

Skin irritation. When treated with a single application of TCS $(0.3 \%)$ on a patch, no irritation was observed in 10 subjects (45). Similar results were observed in a study that evaluated repeated treatment with soap. One study reported irritation in a repeated washing test with soap containing only $2 \% \mathrm{TCS}$, but it was not clear whether this was due to TCS or the soap base (46). Similarly, toothpaste containing TCS did not induce significant irritation. Furthermore, other studies indicated that TCS exerted a protective effect against sodium laurylsulfate (SLS)-induced skin or oral mucosa irritation $(47,48)$. TCS alone, or in combination with SLS, was determined by SCCS to not be a skin or oral mucosal irritant (3).

TCS was applied to the shaved back skin of Pirbright white guinea pigs at a concentrations of $0.1,0.5,1.0$, and $5.0 \%\left(0.1 \mathrm{~mL}\right.$ single application) to a $2 \mathrm{~cm}^{2}$ area. In another study, TCS-soaked $2.5 \mathrm{~cm}^{2}$ gauze patches were applied to the shaved skin or abraded skin of Russian rabbits on their backs and flanks for $24 \mathrm{hr}$ (The TCS concentration was unknown). The TCS did not induce skin irritation at concentrations below $5 \%$, but both studies showed reversible erythema responses $(3,49)$.

In a 14-day repeated-dose study with rats and mice, 1$6 \%$ solutions of TCS were reported to act as severe or potent skin irritants (28-30). In a 90-day subchronic toxicity study, reversible skin irritation was observed in response to $0.5 \%$ TCS in propylene glycol administered at a dose 2 $\mathrm{mL} / \mathrm{kg} / \mathrm{bw}(50)$.

TCS-soaked $2.5 \times 2.5 \mathrm{~cm}^{2}$ gauze was applied to the shaved intact skin or abraded skin on the backs and flanks of six Russian breed rabbits for $24 \mathrm{hr}$ (concentration of TCS unknown). A Draize test was performed for $72 \mathrm{hr}$ after application of the test substance. The erythema response was observed $24 \mathrm{hr}$ after the start of exposure and improved at $72 \mathrm{hr}$. The Draize score of erythema at 24-48 hr reached a maximum of 3 points. Three out of six positive responses were observed on intact skin, and five out of six positive results were observed on abraded skin. The mean Draize scores were 2.5 and 2.8 , respectively. TCS induced a corrosive effect, and it was classified as a moderate irritant based on an overall score of 3.58 (3, 36,48).

No toxicity was observed beyond skin irritation in response to $200 \mathrm{mg} / \mathrm{kg}$ bw/day of TCS in weanling dogs subjected to a subchronic skin toxicity test for 90 days (non-GLP) (51). In a bathing test using neonatal Rhesus monkeys, no toxicity was observed when the animals were exposed to soap solution containing $0.1 \%$ of TCS for 5 min (non-GLP) for 90 days (52).

Mucosal irritation. When $0.3 \%$ TCS in paste was applied once daily to the cheek pouch of hamsters, mucosal irritation was not observed (53). In accordance with

Table 4. Summary of skin and mucosal irritation tests of triclosan

\begin{tabular}{llllc}
\hline \hline Test methods & Species & \multicolumn{1}{c}{ Dose } & \multicolumn{1}{c}{ Results } & Ref. \\
\hline Single patch test & Human & $0.3 \%$ & No skin irritation & 45 \\
\hline Exposure test & Guinea pig & $0.1,0.5,1,5 \%$ & $\begin{array}{l}\text { After } 24 \mathrm{hr}, 4 / 10 \text { animals showed erythema } \\
\text { No symptoms after 48 hr }\end{array}$ & 3 \\
\hline Exposure test & Mouse & $1.5-6 \%$ & $\begin{array}{l}\text { Erythema and peeling of skin } \\
\text { Moderate or severe skin irritation }\end{array}$ & 3 \\
\hline Exposure test & Rat & $1,2 \%$ & $\begin{array}{l}\text { Erythema, edema, cracks, scabs, hair loss, } \\
\text { thickening of the skin, and discoloration } \\
\text { Moderate or severe skin irritation }\end{array}$ & 3 \\
\hline Exposure test & Rat & $0.5 \%$ & Showed reversible skin irritation & 3 \\
\hline Exposure test & Hamster & $0.3 \%$ & No mucosal irritation & 3 \\
\hline Draize test & Rabbit & $0.1 \mathrm{~g}$ & Irritation in cornea, iris, and conjunctiva & 3 \\
\hline
\end{tabular}


Table 5. Summary of skin sensitization tests of triclosan

\begin{tabular}{clllc}
\hline \hline Test methods & Species & Dose & Results & Ref. \\
\hline $\begin{array}{c}\text { Patch, Draize, } \\
\text { maximization test }\end{array}$ & Human & $5-20 \%$ & $\begin{array}{l}\text { The degree of skin reaction was not different from that of } \\
\text { the control group }\end{array}$ & 3 \\
\hline Occluded patch test & Guinea pig & $0.1 \%$ & Test group and negative control showed similar responses & 63 \\
\hline Occluded patch test & Guinea pig & $10 \%$ & $\begin{array}{l}7 / 20 \text { animals showed some erythema but no edema } \\
\text { Very low sensitivity index }\end{array}$ & 62 \\
\hline
\end{tabular}

EPA guidelines, six New Zealand white rabbits were treated with $0.1 \mathrm{~g}$ of TCS, which resulted in ocular mucosal irritation on days 1, 2, 3, 4, and 7 without washing. TCS induced irritation in the cornea, iris, and conjunctiva. On days 1-3, conjunctival redness and conjunctival edema from 0.66 to 2.33 in Draize score (maximum 3 points). Corneal opacity was $0.33-1$ and iritis was $0-1$. In some cases, recovery was not observed on day 7 , but all symptoms fully recovered by day 21. Therefore, direct ocular irritation was observed when $0.1 \mathrm{~g}$ of pure solid TCS was injected into the conjunctival sacs of the left eyes of New Zealand white rabbits (54). Treatment with $1-10 \%$ TCS resulted in only light and reversible eye irritation (55). Table 4 summarizes TCS-induced skin and mucosal irritation.

Skin sensitization. There were no positive skin sensitization responses in the various tests, including repeated patch testing, with up to $20 \%$ inductive capacity and a challenge volume up to $5 \%$ in the patch, Draize and maximization tests $(3,56)$.

Various studies of allergic reactions to TCS (0.5-2\%) in patients with allergies to cosmetics showed that the sensitization response to TCS was less than 1\% (57-59). Sensitization to TCS was very low in a large number of patients. Recently, a case report of sensitization that $2 \%$ TCS detergent aerosol could induce sensitization (60). Therefore, there is need for further studies of individual differences in sensitization and sensitization by inhalation.

Adjuvant and non-adjuvant four studies in guinea pigs, which included a GLP study, reported no evidence of sensitization in response to a relatively high concentration of TCS (up to $10 \%$ in petrolatum) (61-64).

Male and female Pirbright-Hartley guinea pigs were subcutaneously injected with $0.1 \%$ TCS in propylene glycol 6 times for 3 weeks (complete Freund's adjuvant was used at the 2 nd and 3 nd weeks). The first challenge was performed 14 days after the last induction dose, and $0.1 \%$ TCS in $40 \%$ propylene glycol was injected intradermally. The second challenge was performed on 14 days after the first challenge induction, and $0.1 \%$ TCS dissolved in $40 \%$ white petrolatum was used in the occluded patch test for $24 \mathrm{hr}$. The incidence of positive reactions was similar in TCS-treated and control animals $(3,63)$.

In a 'split adjuvant' test with 20 treated and 20 control
Hartley guinea pigs, TCS (10\% in Vaseline) was applied to epilated skin three times. Complete Freund's adjuvant was administered intradermally between the second and third induction doses. After 13 days, 3\% TCS (in petrolatum) was used in the occluded patch test for $24 \mathrm{hr}$ and skin sensitization was measured at 24, 48 and $72 \mathrm{hr}$. After challenge, 7 out of the 20 test animals showed some erythema without edema and vesicle formation, which resolved after 1 or 2 days. In a stimulation test, erythema was observed in one out of 20 animals, and this erythema did not resolve at $72 \mathrm{hr}$, but no edema was observed. Since no response was seen in the control group, it was concluded that TCS had a very low skin sensitization index $(3,35,62)$. Table 5 summarizes skin sensitization in response to TCS.

Neurotoxicity. In a neurotoxicity study, albino SIV50 rats were dosed by gavage for 14 days with $0,100,300$, 1,000 or $2,000 \mathrm{mg} / \mathrm{kg}$ bw/day of TCS. At the highest dose 17 animals died and exhibited decreased body weights. Clinical symptoms such as decreased exercise, decreased muscle tension, obesity, and polyuria were observed at doses of $300 \mathrm{mg} / \mathrm{kg}$ bw/day and higher. No differences in brain weights were observed between the treated and control group. There was no evidence of neuropathology in response to any dose, as determined by examination of brain and sciatic nerve tissues. Based on these observations, NOAEL was set at $100 \mathrm{mg} / \mathrm{kg}$ bw/day (3).

Reproductive and developmental toxicity. General reproductive and developmental toxicity and teratogenicity caused by TCS were not observed. Some toxicity, such as fetal weight loss, was thought to be an indirect consequence of toxicity from dams. TCS did not induce sex ratio changes or act as an endocrine disruptor. However, some recent studies have demonstrated developmental toxicity. TCS is similar in structure to endocrine disruptors, steroids, and thyroid hormones. Therefore further research of potential endocrine disruption effects is needed.

In a second-generation reproductive developmental toxicity study (GLP-compliant, OECD: No. 416 consistent) on $\mathrm{CD}^{\circledR}(\mathrm{SD})$ rats, the overall NOAEL was determined to be $1,000 \mathrm{ppm}(\sim 65 \mathrm{mg} / \mathrm{kg}$ bw/d for males and females, combined), based on a slight reduction in pup weight and survival in the high-dose group. The NOAEL for repro- 
duction and pregnancy was considered offset at 3,000 ppm ( $203 \mathrm{mg} / \mathrm{kg}$ bw/day) (65). No second-generation reproductive toxicity was observed in a similar study using Colworth Wistar rats, with no toxic effects observed in response to $300 \mathrm{mg} / \mathrm{kg}$ bw/day of TCS during pregnancy (66).

TCS was administered to Wistar rats at doses of $0,1,10$, and $50 \mathrm{mg} / \mathrm{kg} /$ day from the 8 th day before pregnancy until post-natal day 21. Sex ratio reduction was observed at a dose of $1 \mathrm{mg} / \mathrm{kg} /$ day (67). In this study, the live birth index and 6-day survival index decreased in response to high dose $(50 \mathrm{mg} / \mathrm{kg} /$ day $)$ TCS. Female pup body weight was also decreased compared to that in the control group. Delays in sexual maturation in females was observed in response to all doses. However, uterus weights did not change.

Similar studies showed reductions in luteinizing hormone (LH) and follicle-stimulating hormone (FSH) in male rats treated with TCS (60-day repeated oral administration). These changes could affect puberty development $(68,69)$. Testes, seminal vesicles, ventral prostate, epididymis, and vas deferens weights were reduced in the $10 \mathrm{mg} /$ $\mathrm{kg}$ /day dose group compared to the control group. Biochemical changes and decreases LH, FSH, cholesterol, pregnenolone and testosterone concentrations were observed in the $20 \mathrm{mg} / \mathrm{kg}$ /day dose group (69).

In pubertal exposure studies, $150 \mathrm{mg} / \mathrm{kg} /$ day of TCS induced estrogenic effects such as increased vaginal opening $(150 \mathrm{mg} / \mathrm{kg} /$ day, a result that conflicted with the results obtained by Rodriguez and Sanchez (67)) and increased uterine weight (70). In addition, in a uterotrophic assay, TCS improved the uterine response to ethinylestradiol, but did not induce uterine weight or histopathologic changes. The dose of $4.69 \mathrm{mg} / \mathrm{kg} /$ day of TCS required to produce these effects corresponded to about 10 times the human blood concentration of TCS observed in humans (0.01-38 $\mathrm{ng} / \mathrm{mL})$. However, the elimination half-life in rats was slower than in humans $(71,72)$.

In a GLP-study of teratogenicity with $\mathrm{Crl}$ : $\mathrm{CD}^{\circledR}-1$ (ICR) mice, maternal NOEL was $25 \mathrm{mg} / \mathrm{kg}$ bw/day based on liver discoloration and liver weight gain and fetal NOEL was $25 \mathrm{mg} / \mathrm{kg}$ bw/day based on fetal weight reduction and ossification reduction. Low NOAEL was likely due to mice being sensitive to hepatotoxicity (73).

Another study using $\mathrm{CD}^{\circledR}$ (S-D) rats showed that the maternal NOEL was $50 \mathrm{mg} / \mathrm{kg}$ bw/day based on reduction of food intake at high concentrations, and fetal NOEL was $50 \mathrm{mg} / \mathrm{kg}$ bw/day based on ossification delay at high doses (74).

TCS was orally administered to 5-month-old New Zealand white rabbits at 15,50 , and $150 \mathrm{mg} / \mathrm{kg}$ bw/day. Administration occurred from 6th to 18th days of pregnancy. A pathology examination for external and internal malformation was performed to determine maternal and fetal toxicity. Body weights in the $150 \mathrm{mg} / \mathrm{kg}$ bw/day group
TCS decreased by $5.1 \%$ on the 10th day of pregnancy and $7.9 \%$ on the 16th day when compared with control group. At 6-8 and 12-14 days, decreased body weight was observed. Animals in the $150 \mathrm{mg} / \mathrm{kg}$ bw/day group also showed reduced food intake by $7 \%$ on day 11 and $41 \%$ on day 14 when compared to control group. The autopsy results were not significant, and fetal weight, sex ratio, and external and internal malformations did not differ between the treatment and control groups. As a result, no toxicity was observed at 15 or $50 \mathrm{mg} / \mathrm{kg}$ bw/day, so the NOAEL value for maternal toxicity was set at $50 \mathrm{mg} / \mathrm{kg} \mathrm{bw} /$ day. The LOAEL of maternal toxicity was set at $150 \mathrm{mg} / \mathrm{kg}$ bw/day based on body weights, body weight gains, and reduced food intake. The NOAEL value for developmental toxicity was $150 \mathrm{mg} / \mathrm{kg}$ bw/day. And the NOAEL value for teratogenicity was set at $150 \mathrm{mg} / \mathrm{kg}$ bw/day $(3,35,75)$.

Pregnant female S-D rats (11 weeks old, 5 rats per group) were orally treated with $\operatorname{TCS}(5,10,25,50$, and 75 $\mathrm{mg} / \mathrm{kg}$ bw/day). TCS was administered for 10 days from the 6 th to 15 th days of pregnancy. Euthanasia was performed on the 20th day of pregnancy and pathology examinations were performed. No animals died during the experiment prior to sacrifice. In the $75 \mathrm{mg} / \mathrm{kg} \mathrm{bw} /$ day group, weight gain from 10 to 16 days of gestation was $40 \%$ lower than that in the control group, and body weight gain from 6 to 16 days was $29.6 \%$ less than that in the control group. There were no differences in fetal weight, sex ratio, or external and internal malformations. As a result, the NOAEL value for maternal toxicity was set at $50 \mathrm{mg} / \mathrm{kg}$ bw/day. The LOAEL of maternal toxicity was $75 \mathrm{mg} / \mathrm{kg}$ bw/day based on weight gain reduction. The NOAEL value for developmental toxicity was $50 \mathrm{mg} / \mathrm{kg}$ bw/day. The NOAEL value for teratogenicity was $75 \mathrm{mg} /$ $\mathrm{kg}$ bw/day $(3,76)$.

TCS $(0,15,50$, and $150 \mathrm{mg} / \mathrm{kg}$ bw/day) was orally administered to pregnant rats (S-D) (24 rats per group) at 13 weeks of age. Euthanasia was performed on the 20th day of pregnancy, and external morphology and pathology examinations were performed. On 20th day of pregnancy, liver weight was measured for all dams and ratios of the liver weights compared to the body weights of each animal were calculated. In addition, the number of dead and live fetuses in the uteruses of dams was evaluated, and ovaries were dissected to confirm the number of luteal bodies. Gender, external deformities and changes to the internal organs of the thorax and abdomen were identified in the fetuses, and no animals died during the test period. In the $150 \mathrm{mg} / \mathrm{kg}$ bw/day administration group, food intake was decreased at 6-11 days of gestation when compared with the control group. No other significant differences were detected. Fetal weight, sex ratio, and external and internal malformations were not significantly different from the control group. As a result, the NOAEL value for maternal toxicity was $50 \mathrm{mg} / \mathrm{kg}$ bw/day. Based on reduced 
Table 6. Summary of reproductive and developmental toxicity studies of triclosan

\begin{tabular}{|c|c|c|c|c|c|}
\hline Route & Species & Exposure period & Dose & Results & Ref. \\
\hline Oral & Rat & $\begin{array}{l}10 \text { weeks prior } \\
\text { to mating }(2 \\
\text { generations) }\end{array}$ & $\begin{array}{l}\text { Male: } 17,56,176 \\
\mathrm{mg} / \mathrm{kg} \text { bw/day } \\
\text { Female: } 23,73,229 \\
\mathrm{mg} / \mathrm{kg} \text { bw/day }\end{array}$ & $\begin{array}{l}\text { NOAEL } 56-73 \mathrm{mg} / \mathrm{kg} \text { bw/day } \\
\text { At } 176-229 \mathrm{mg} / \mathrm{kg} \text { bw/day dose, the weight and } \\
\text { survival rate of the fetus decreased slightly. } \\
\text { The maternal and first-generation reproductive } \\
\text { toxicity NOAEL was } 176-229 \mathrm{mg} / \mathrm{kg} \text { bw/day. }\end{array}$ & 3 \\
\hline Oral & Rat & $\begin{array}{l}\text { 8th day before } \\
\text { pregnancy to } \\
\text { post-natal } \\
\text { day } 21\end{array}$ & $\begin{array}{l}1,10,50 \mathrm{mg} / \mathrm{kg} \\
\text { bw/day }\end{array}$ & $\begin{array}{l}\text { Decreased male/female ratio at doses of } 1 \mathrm{mg} / \\
\mathrm{kg} \text { bw/day } \\
\text { At a dose of } 50 \mathrm{mg} / \mathrm{kg} \mathrm{bw} / \text { day, the normal birth } \\
\text { index and 6-day survival index decreased. } \\
\text { Delays in sexual maturity in females were seen } \\
\text { for all doses. }\end{array}$ & 67 \\
\hline Oral & Mouse & $\begin{array}{l}\text { 6-15 days during } \\
\text { pregnancy }\end{array}$ & $\begin{array}{l}10,25,75,350 \mathrm{mg} / \\
\mathrm{kg} \mathrm{bw} / \text { day }\end{array}$ & $\begin{array}{l}\text { Maternal and fetal NOEL was } 25 \mathrm{mg} / \mathrm{kg} \text { bw/day } \\
\text { Maternal liver discoloration and liver weight } \\
\text { increase were observed and fetuses exhibited } \\
\text { weight reduction and ossification delay }\end{array}$ & 3 \\
\hline
\end{tabular}

food intake, the LOAEL of maternal toxicity was $150 \mathrm{mg} /$ $\mathrm{kg}$ bw/day. The NOAEL value for developmental toxicity was $50 \mathrm{mg} / \mathrm{kg}$ bw/day. The NOAEL value for teratogenicity was set at $150 \mathrm{mg} / \mathrm{kg}$ bw/day $(3,35)$.

TCS was fed at doses of $10,25,75$, and $350 \mathrm{mg} / \mathrm{kg} \mathrm{bw} /$ day to 25 pregnant female mice (CD-1). The period of administration was 10 days from the 6th to 15 th days of pregnancy. Aborted or premature mice were autopsied to investigate lesions. Surviving dams were euthanized on the 18th day of pregnancy. The number of dead and live fetuses was assessed, and reabsorption in dead fetuses was evaluated based on degree of degradation. Weight, sex, external deformities, and other fetal changes were observed. A statistically significant, biologically relevant increase in body weight and weight gain was observed in response to $350 \mathrm{mg} / \mathrm{kg}$ bw/day of TCS compared to the control group. This increase correlated with increased liver weight observed at autopsy. In addition, the number of mice with yellowish brown areas in the liver was significantly increased. A similar case was seen in the $75 \mathrm{mg} / \mathrm{kg}$ bw/day group, though the differences between the treated and control groups were not statistically significant. Liver weight was markedly increased in response to high dose TCS. The absolute mean liver weights were $2.57 \mathrm{~g}$ in the control group, $2.75 \mathrm{~g}$ in the $75 \mathrm{mg} / \mathrm{kg}$ bw/day group, and $3.92 \mathrm{~g}$ in the $350 \mathrm{mg} / \mathrm{kg}$ bw/day group. The relative liver weights in the two treated groups were also significantly increased compared with those in the control group. In addition, fetal weight loss was observed in the treated groups. In a preliminary experiment to set the dose range, fetal weight loss was observed in the $40 \mathrm{mg} / \mathrm{kg}$ bw/day group. No other effects were noted. The incidence of small changes in anterior cranial ossification in fetuses was markedly increased in response to 75 and $350 \mathrm{mg} / \mathrm{kg}$ bw/day of TCS. In the $350 \mathrm{mg} / \mathrm{kg}$ bw/day group, the rate of change in anterior cranial ossification in dams was also significantly increased. The mean values of ossified phalanx of forelimbs and hindlimbs were significantly $(p<0.01)$ decreased in the $350 \mathrm{mg} / \mathrm{kg}$ bw/day group compared to the control group. In this group, formation of ossification was delayed due to TCS-related low fetal weight. As a result, the NOAEL value for maternal toxicity was $25 \mathrm{mg} / \mathrm{kg}$ bw/day. The NOAEL value for teratogenicity was $25 \mathrm{mg} / \mathrm{kg}$ bw/day $(2,3,73)$. Reproductive toxicity is summarized in Table 6 .

Genotoxicity. In vitro bacterial gene mutation assay studies showed that TCS did not induce mutation regardless of S9 metabolism activation (77). This test was performed before implementation of the OECD guidelines. Genotoxicity was not observed in studies conducted according to the OECD guidelines.

Mutagenicity tests using Saccharomyces cerevisiae performed before the implementation of the OECD guidelines did not show positive results (77). Irgasan DP 300 (TCS, $>99 \%$ pure), used at a concentration of $0.2 \mathrm{mg} / \mathrm{mL}$, was reported to cause mutations, but only one concentration was used, the batch number was not reported, and this test has limited value (3). In vitro gene mutation assay with mouse lymphoma cells, although not performed according to OECD guidelines, did not induce mutations as determined by mouse lymphoma assay for tk locus (78). In vitro unscheduled DNA synthesis test was negative using the rat hepatocyte test (this was not performed according to OECD guidelines) (79). In vitro chromosome aberration test using Chinese hamster ovary (CHO-K1-BH4) cells showed no clastogenic activity. However, SCCS determined this to be insufficient to draw conclusions based on weak dose-dependent effects (80). SCCS determined that a conclusion of no clastogenic activity could not be reached because of a weak dose-dependent effect $(23,80)$. A simi- 
lar study using Chinese hamster V79 cells reported that 0.1-3 $\mu \mathrm{g} / \mathrm{mL}$ FAT 80'23/Q (TCS trade name) increased abnormal cells and thus induced mutations (81).

Host-mediated assay with albino NMRI mice did not induce mutations in S. typhimurium (77). Mutations were not induced in host-mediated assay studies of mouse lymphoma cells derived from DBA/2f/Bom mice (82). Two studies of mouse spot tests reported that a non-toxic dose of $2 \mathrm{mg} / \mathrm{kg}$ bw did not cause mutations (83), and one study reported that TCS induced mutations (23). These studies were not conducted in accordance with OECD guidelines and the applicability of the results was limited.

Bone marrow chromosome aberration test using Chinese hamsters (Cricetulus griseus) reported no genotoxicity at $600 \mathrm{mg} / \mathrm{kg}$ bw $\left(1 / 3\right.$ of $\left.\mathrm{LD}_{50}\right)(84)$. This study was conducted prior to implementation of the OECD guidelines. Bone marrow chromosome aberration test using Wistar rats performed according to OECD 475 (1984) did not cause genotoxicity such as chromosome breakage (81). The micronucleus test was negative in bone marrow of mice (78). No nuclear abnormalities were observed in the nucleus malformation test on somatic interphase nuclei of Chinese hamsters (85). TCS was not genotoxic in the sex linked recessive lethal test in Drosophila melanogaster (86). Dominant lethal test in mice and chromosome aberration test in male germinal epithelium of mice were negative $(87,88)$.

Carcinogenicity. TCS has not been reported as a carcinogen by the International Agency for Research on Cancer (IARC). Carcinogenicity of TCS was not reported in rats and hamsters. According to the results of a mouse study, TCS induced adenoma or carcinoma after 18 months of treatment with $0,10,30,100,200 \mathrm{mg} / \mathrm{kg}$ bw/day in 6 , 10, 17, 32, and 42 males and 0, 1, 3, 6, and 20 females, respectively $(3,41)$ (Table 7$)$. In mice, there was a possibility of liver cancer in response to lifetime dosing at $30 \mathrm{mg} / \mathrm{kg}$ bw/day. However, it should be noted that TCS was classified as a peroxisome proliferator in mice. These substances are not likely to cause liver cancer in humans. Currently in Europe, TCS is not classified as a carcinogen.

TCS was administered to male and female rats (S-D) with food at doses of $0,300,1,000$, and 3,000 ppm, once per day, for 52 or 104 weeks. Twenty rats were included in each 52-week groups, 60 rats were used in each 104-week groups. There was no evidence of carcinogenesis for 52 weeks or 104 weeks of treatment. And weight change, organ weight, pathological examination, histologic examination were considered unrelated to treatment $(3,42)$.

TCS was administered at doses of $12.5,75$ and $250 \mathrm{mg} /$ $\mathrm{kg} /$ day for 90-95 weeks with diet including 5 animals per group (male and female Syrian hamsters). The mortality rate was increased in $250 \mathrm{mg} / \mathrm{kg} /$ day male. Nephropathy was also found in response to this dose $(20,35,43)$.

For 18 months, TCS was transdermally administered to male and female mice (CD-1) 3 times per week. Five animals per sex and group were sprayed with $0.1 \mathrm{~mL}$ of $0.5 \%$ or $1 \%$ TCS dissolved in acetone. Pathologic examination showed that $0.5 \%$ and $1 \%$ TCS did not exert carcinogenic effects in mice (41).

For 18 months, 50 animals per group of male and female Albino mice were orally administered (in feed) TCS at doses of $0,10,30$, and $100 \mathrm{ppm}(\mathrm{w} / \mathrm{w})$. Pathologic examinations showed higher mortality rates in the $100 \mathrm{ppm}$ male group than in the $0 \mathrm{ppm}$ male group. However, the observed mortality rate was within the normal range. In females, there were no significant difference from the control group, and no abnormalities were observed during tissue examination (89).

Phototoxicity. No photosensitization was observed in guinea pigs, mice and pigs when TCS was used at concentration up to $1 \%$. However, these results were obtained prior to implementation of the OECD guidelines $(3,90)$.

Toxicokinetics. TCS was slowly absorbed by the transdermal route, while oral absorption was rapid. Transdermal absorption was less than $10 \%$, and oral absorption

Table 7. Summary of carcinogenicity studies of triclosan

\begin{tabular}{|c|c|c|c|c|c|}
\hline Route & Species & Exposure period & Dose & Results & Ref. \\
\hline Oral & Mouse & 18 months & $\begin{array}{r}10,30,100,200 \\
\mathrm{mg} / \mathrm{kg} \text { bw/day }\end{array}$ & $\begin{array}{l}\text { Adenomas or carcinomas were observed in the } \\
\text { liver in } 6,10,17,32 \text {, and } 42 \text { males, respectively } \\
\text { and } 0,1,3,6 \text {, and } 20 \text { females, respectively. } \\
\text { Triclosan in mice should be classified as a per- } \\
\text { oxisome proliferator with the possibility to } \\
\text { cause liver cancer at a } 30 \mathrm{mg} / \mathrm{kg} \text { bw/day dose, } \\
\text { but it is estimated that the possibility of liver } \\
\text { cancer is not high in humans. }\end{array}$ & 3 \\
\hline Oral & Hamster & 90-95 weeks & $\begin{array}{l}12.5,75,250 \\
\mathrm{mg} / \mathrm{kg} \text { bw/day }\end{array}$ & $\begin{array}{l}\text { Increased mortality and nephropathy at doses of } \\
250 \mathrm{mg} / \mathrm{kg} \text { bw/day }\end{array}$ & 43 \\
\hline Dermal & Mouse & 18 months & $0.5,1 \%$ & No carcinogenicity & 41 \\
\hline
\end{tabular}


was nearly $100 \%$ (22). TCS was mainly distributed in liver, lung, kidney, gastrointestinal tract, gallbladder. In humans, it was found in plasma, urine, breast milk (4-7) and in mice, TCS could be accumulated (35). The main route of TCS elimination is urine, and feces is a secondary route in human $(55,70,91,92)$. According to US FDA, more than $90 \%$ of the permeated TCS was metabolized (1), and in humans, up to $87 \%$ of the absorbed TCS was excreted in urine within $72 \mathrm{hr}$ (93). Following oral administration, halflife was 13-29 hr, 10-15 hr, 8-12 hr, and 25-32 hr in human, rat, mouse and hamster, respectively. The main excretion route in humans, rabbits, hamsters, and primates was via urine and slightly excretion via feces. In rats, mice and beagle dogs, bile excretion was greater than excretion via kidney. In humans, bioaccumulation following oral and transdermal administration was not observed (8-12).

Park et al. (13) evaluated urinary TCS concentrations in 6,288 adults (2,692 men and 3,596 women) using personal care products based on the Second Korean National Environmental Health Survey (KoNEHS 2012-2014). The odds ratios (ORs) of urinary concentrations of TCS in males and females using personal care products were 0.961.67 and 1.03-1.33, respectively. These results showed that greater use of personal care products, resulted in increased exposure to TCS and increased urinary excretion. Based on these results, it was concluded that the concentration of TCS in urine increases with frequent use of personal care products (13).

Percutaneous absorption. When applied to full thickness human skin, the amount of TCS permeated was different for each of the following formulations: $12 \%$ for dishwashing liquid, $11.3 \%$ for water/oil emulsion, $7.65 \%$ for deodorant and $7.2 \%$ for soap solution (2).

When applied as an ethanol suspension, an ethanol/water suspension, a soap suspension and a cream, rats showed $23-28 \%$ absorption. When applied to human oral epithelium in the form of toothpaste, TCS absorption was $5-10 \%$ (3,7,94-96).

The worst-case scenario involves a worker (mean body weights $70 \mathrm{~kg}$ ) using a surface cleaner or detergent containing $0.3 \%$ TCS for $8 \mathrm{hr}$ per day and 5 days per week.

Table 8. Summary of percutaneous absorption rates of triclosan

\begin{tabular}{|c|c|c|c|c|c|}
\hline Species & Route & $\begin{array}{l}\text { Exposure } \\
\text { period }\end{array}$ & Dose & Absorption & Ref. \\
\hline \multirow[t]{3}{*}{ Rat } & \multirow[t]{3}{*}{ Dermal } & \multirow[t]{3}{*}{$48 \mathrm{hr}$} & $\begin{array}{l}0.2 \mathrm{~mL} \text { ethanol containing } 162 \mu \mathrm{g} \text { of triclosan } \\
\text { was applied to } 7.5 \mathrm{~cm}^{2} \text { of clipped dorsal female } \\
\text { rat skin. }\end{array}$ & $28 \%$ & \multirow[t]{3}{*}{94} \\
\hline & & & $\begin{array}{l}0.1 \mathrm{~mL} \text { of } 0.05,0.1,0.5,1.0,2.0 \%(\mathrm{w} / \mathrm{v}) \text { solutions } \\
\text { of shampoo were applied to } 7.5 \mathrm{~cm}^{2} \text { of skin. }\end{array}$ & $3-4 \%$ & \\
\hline & & & $\begin{array}{l}0.1 \%(\mathrm{w} / \mathrm{v}) \text { solution of deodorant was sprayed for } \\
2 \mathrm{sec} \text { at distance of } 15 \mathrm{~cm} \text { on } 7.5 \mathrm{~cm}^{2} \text { of back skin. }\end{array}$ & $52 \%$ & \\
\hline \multirow[t]{3}{*}{ Rat } & \multirow[t]{3}{*}{ Dermal } & $96 \mathrm{hr}$ & $\begin{array}{l}\text { The vehicle were solvents (ethanol, acetone), the } \\
\text { exact dosage is unknown. }\end{array}$ & $93 \%$ & \multirow[t]{3}{*}{100} \\
\hline & & $48 \mathrm{hr}$ & $\begin{array}{l}\text { The vehicle was cream, the exact dosage is } \\
\text { unknown. }\end{array}$ & $23 \%$ & \\
\hline & & $144 \mathrm{hr}$ & $\begin{array}{l}\text { The vehicle was vaseline, the exact dosage is } \\
\text { unknown. }\end{array}$ & $73 \%$ & \\
\hline Rat & Dermal & $24 \mathrm{hr}$ & $\begin{array}{l}100 \mathrm{~mL} \text { of } 64.5 \mathrm{mM} \text { triclosan solution }(6.92 \mathrm{MBq}) \\
\text { was applied to } 9.6 \mathrm{~cm}^{2} \text { of skin. }\end{array}$ & $21 \%$ & 96 \\
\hline Rat & Dermal & $72 \mathrm{hr}$ & $\begin{array}{l}\text { The vehicle was a soap suspension, the exact dos- } \\
\text { age is unknown. }\end{array}$ & $28 \%$ & 95 \\
\hline Human & $\begin{array}{l}\text { Oral } \\
\text { epithelium }\end{array}$ & - & $\begin{array}{l}\text { Exact dose not applicable when dosing with com- } \\
\text { mon toothpaste }\end{array}$ & $5-10 \%$ & 8 \\
\hline $\begin{array}{l}\text { Full thickness } \\
\text { human skin }\end{array}$ & Dermal & - & The exact dosage is unknown. & $\begin{array}{l}\text { Dishwashing liquid: } 12 \% \text {, } \\
\text { water/oil emulsion: } 11.3 \% \text {, } \\
\text { deodorant: } 7.65 \% \text {, } \\
\text { soap solution: } 7.2 \%\end{array}$ & 3 \\
\hline Human & Dermal & $8 \mathrm{hr}$ & $\begin{array}{l}\text { Exposed skin area for both hands or a hand and a } \\
\text { forearm was } 1,000 \mathrm{~cm}^{2} \text {. } \\
\text { Thickness of the liquid layer on the skin was } 0.01 \mathrm{~cm} \text {. }\end{array}$ & $14 \%$ & 35 \\
\hline
\end{tabular}


Table 9. Summary of NOAELs for triclosan

\begin{tabular}{|c|c|c|c|c|c|c|c|}
\hline $\begin{array}{l}\text { Test } \\
\text { methods }\end{array}$ & Animal & Route & $\begin{array}{c}\text { Duration } \\
\text { of treatment }\end{array}$ & Dose & Test items & Results & Ref. \\
\hline $\begin{array}{l}\text { Repeated } \\
\text { dose }\end{array}$ & Mouse & Diet & 28 day & $\begin{array}{l}50,1,000 \mathrm{ppm} \\
\text { (male: } 6.48 \\
113 \mathrm{mg} / \mathrm{kg} / \\
\text { day, female: } \\
8.28,169 \\
\mathrm{mg} / \mathrm{kg} / \text { day) }\end{array}$ & $\begin{array}{l}\text { Hematological observation, } \\
\text { Histological observation }\end{array}$ & $\begin{array}{l}\text { Increased ALT, AST activity in } \\
\text { males at } 50 \text { ppm, decreased } \\
\text { phosphate in females } \\
1,000 \text { ppm decreased red blood } \\
\text { cell count, hemoglobin, hema- } \\
\text { tocrit in male and female. } \\
\text { Increased ALT, AST activity, } \\
\text { hypertrophy of liver } \\
\text { NOAEL } 50 \text { ppm, LOAEL 1,000 } \\
\text { ppm }\end{array}$ & 32 \\
\hline $\begin{array}{l}\text { Repeated } \\
\text { dose }\end{array}$ & $\begin{array}{l}\text { Syrian } \\
\text { hamster }\end{array}$ & Diet & 13 weeks & $\begin{array}{l}0,75,200 \\
350,750 \\
900 \mathrm{mg} / \mathrm{kg} \\
\text { bw/day }\end{array}$ & $\begin{array}{l}\text { Dietary intake, Hematologi- } \\
\text { cal observation, Histologi- } \\
\text { cal observation }\end{array}$ & $\begin{array}{l}\text { Kidney discoloration, granule for- } \\
\text { mation, renal toxicity observed } \\
\text { at } 750,900 \mathrm{mg} / \mathrm{kg} \text { bw/day } \\
\text { Renal toxicity observed at } 350 \\
\mathrm{mg} / \mathrm{kg} \text { bw/day } \\
\text { Increased water intake at } 200 \\
\mathrm{mg} / \mathrm{kg} \text { bw/day and decreased } \\
\text { urine osmotic pressure } \\
\text { NOAEL } 75 \mathrm{mg} / \mathrm{kg} \mathrm{bw} / \text { day, } \\
\text { LOAEL } 200 \mathrm{mg} / \mathrm{kg} \mathrm{bw} / \text { day }\end{array}$ & 36 \\
\hline $\begin{array}{l}\text { Repeated } \\
\text { dose }\end{array}$ & $\begin{array}{l}\text { Baboon } \\
\text { monkey }\end{array}$ & - & 1 year & - & $\begin{array}{l}\text { Macroscopy, Hematologi- } \\
\text { cal observation, Histologi- } \\
\text { cal observation }\end{array}$ & $\begin{array}{l}\text { Hemoglobin and clinical chemis- } \\
\text { try changes were observed } \\
\text { during the administration } \\
\text { period of } 300 \mathrm{mg} / \mathrm{kg} \mathrm{bw} / \mathrm{day} \text {, } \\
\text { but no histological changes } \\
\text { were observed. } \\
\text { NOAEL } 30 \mathrm{mg} / \mathrm{kg} \mathrm{bw} / \text { day }\end{array}$ & 93 \\
\hline $\begin{array}{l}\text { Repeated } \\
\text { dose }\end{array}$ & Rat & Diet & 104 weeks & $\begin{array}{l}0,300,1,000 \\
3,000 \mathrm{ppm} \\
\text { (male: } 0,12 \\
40,127 \mathrm{mg} / \\
\mathrm{kg} \text { bw/day } \\
\text { female: } 0,17 \text {, } \\
56,190 \mathrm{mg} / \\
\mathrm{kg} \text { bw/day) }\end{array}$ & $\begin{array}{l}\text { Hematological observation, } \\
\text { Histological observation, } \\
\text { Clinical pathologic obser- } \\
\text { vation }\end{array}$ & $\begin{array}{l}\text { Hematological changes, } \\
\text { increased concentration of } \\
\text { hemoglobin response to } 1,000 \text {, } \\
3,000 \mathrm{ppm} \text { in females and } 300 \\
\text { ppm in males, increased coagu- } \\
\text { lation time in high-dose group } \\
\text { males, WBC reduction in } \\
\text { females } \\
\text { Increased or decreased tissue } \\
\text { weight at high and medium } \\
\text { concentrations. The experi- } \\
\text { menter estimateds NOAEL to } \\
\text { be } 48 \mathrm{mg} / \mathrm{kg} / \text { day } \\
\text { Suggested } 12 \mathrm{mg} / \mathrm{kg} / \text { day for } \\
\text { SCCP }\end{array}$ & 3,42 \\
\hline $\begin{array}{l}\text { Repeated } \\
\text { dose }\end{array}$ & $\begin{array}{l}\text { Syrian } \\
\text { hamster }\end{array}$ & Diet & 95 weeks & $\begin{array}{c}12.5,75,250 \\
\mathrm{mg} / \mathrm{kg} / \text { day }\end{array}$ & $\begin{array}{l}\text { Hematological observation, } \\
\text { Histological observation }\end{array}$ & $\begin{array}{l}\text { At } 250 \mathrm{mg} / \mathrm{kg} \text { bw/day, increase in } \\
\text { drinking water intake, increase } \\
\text { in mean particulate blood pig- } \\
\text { ment concentration, increase in } \\
\text { reticulocyte count, platelet } \\
\text { reduction } \\
\text { LOAEL } 250 \mathrm{mg} / \mathrm{kg} \text { bw } / \text { day } \\
\text { NOAEL } 75 \mathrm{mg} / \mathrm{kg} \text { bw } / \text { day }\end{array}$ & 43 \\
\hline
\end{tabular}

ALT, Alanine aminotransferase; AST, Aspartate aminotransferase; NOAEL, No-observed-adverse-effect level; LOAEL, Lowest-observedadverse-effect level; WBC, White blood cell; SCCP, Scientific Committee on Consumer Products of the European Commission's Directorate-General for Health and Consumer Protection. 
The exposed skin area of both hands or hands and forearms was $1,000 \mathrm{~cm}^{2}$, and the thickness of the liquid layer on the skin was $0.01 \mathrm{~cm}$. The assessment of skin exposure to end-users was based on the European Commission's Technical Guidelines for Risk Assessment (97). The math formula of the EU guideline was modified, and the calculated percutaneous absorption rate of TCS was 14\% (35). The percutaneous absorption rate of TCS are summarized in Table 8.

\section{DOSE-RESPONSE ASSESSMENT}

The results of the 104 week repeated dose toxicity study of TCS in rats showed that the concentration of hemoglobin was increased in response to $127 \mathrm{mg} / \mathrm{kg}$ bw/day of TCS in males and $190 \mathrm{mg} / \mathrm{kg}$ bw/day of TCS in females. Based on these results, the NOAEL was $48 \mathrm{mg} / \mathrm{kg}$ bw/day. However, at a dose of $56 \mathrm{mg} / \mathrm{kg}$ bw/day or higher in females, increased hemoglobin concentrations and spleen weights were observed. Based on these results, SCCS determined a NOAEL of $12 \mathrm{mg} / \mathrm{kg}$ bw/day (3) (Table 9). Therefore, this value was selected as the toxicity reference value. Table 9 summarizes toxicity reference values for TCS.

\section{EXPOSURE ASSESSMENT}

Exposure assessment of TCS was estimated based on the cosmetic usage of Koreans, dermal absorption rate, TCS concentration in products, and body weight according to the available cosmetic risk assessment guideline by MFDS (23). The amount of cosmetics daily used was directly measured based on the actual usage of each cosmetic product in Korean populations (98). Representative cosmetic products included 16 product types of shower gel, hand-washing soap, shampoo, hair conditioner, body lotion, face cream, hand cream, deodorant, hair styling, wet wipe, liquid foundation, make-up remover, eye makeup, maskara, lipstick, and eyeliner. The systemic exposure dosage (SED) of TCS has been derived by two scenarios depending on the cosmetics usage of Koreans. The first scenario is the combined use of representative cosmetics and oral care products. Oral care products of toothpaste and mouthwash are classified as quasi drug and not cosmetics in Korea. However, TCS was used in toothpaste (up to $0.3 \%$ ) and mouthwash (up to $0.02 \%$ ) for oral care. The second scenario is the combined use of rinse-off products of cleansing, deodorants, coloring products, and oral care products. The SED was calculated to be $0.14337 \mathrm{mg} /$ $\mathrm{kg}$ bw/day for the first scenario. When rinse-off body cleansing products containing $0.3 \%$ TCS (shower gel, hand wash soap), deodorants, coloring agent (except eyes and lips), and oral care products were used in parallel, the SED was calculated at $0.04733 \mathrm{mg} / \mathrm{kg}$ bw/day (Table 10). Dermal SED was calculated by assuming 14\% dermal absorption of TCS, which is the highest experimental value determined in human in vivo skin absorption studies $(35,99)$. The dermal SED was calculated according to the following equation:

$\mathrm{SED}=$

$\frac{\mathrm{A}(\mathrm{g} / \mathrm{day}) \times 1,000 \mathrm{mg} / \mathrm{g} \times \mathrm{C}(\%) / 100 \times \mathrm{DAp}(\%) / 100}{60 \mathrm{~kg}}$

Table 10. Systemic exposure dose (SED) of triclosan from cosmetic products in Koreans

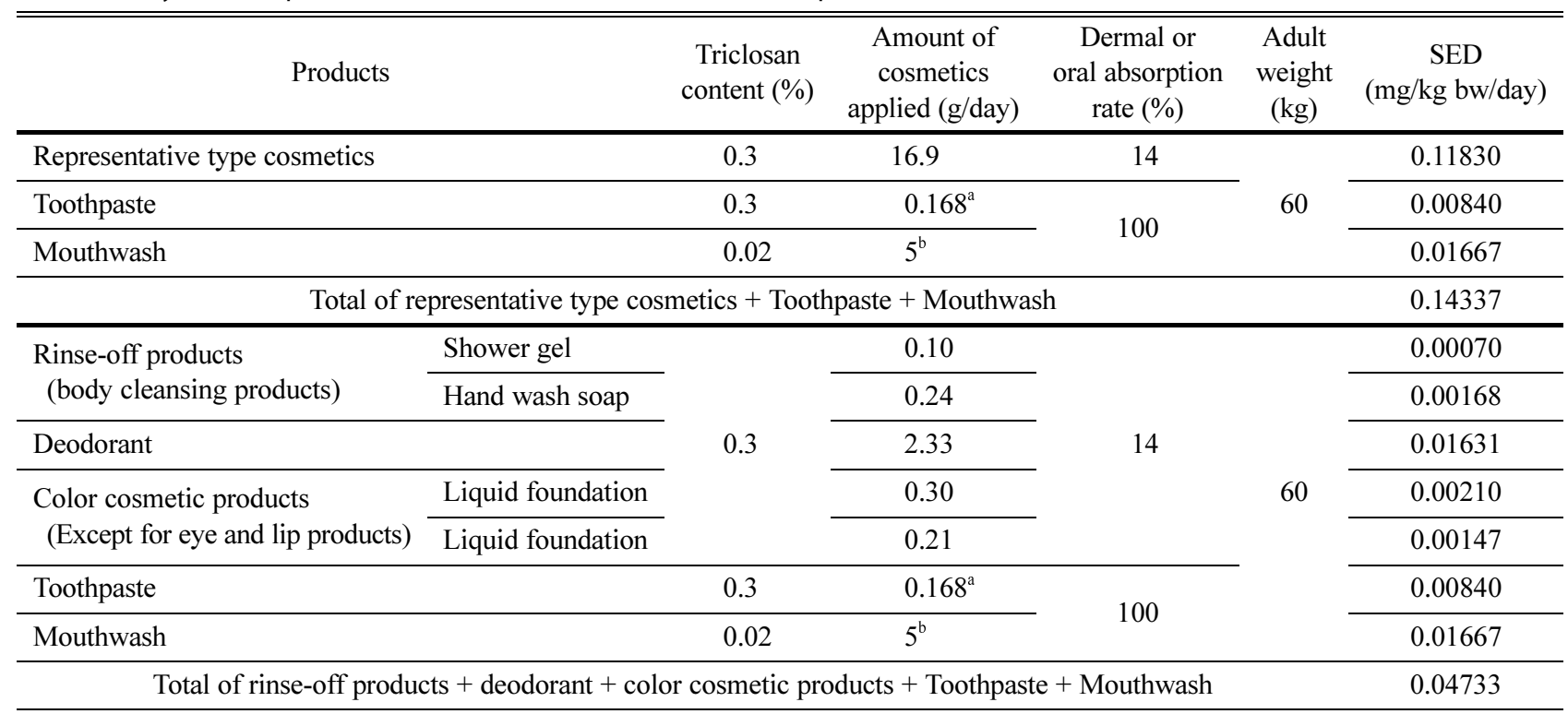

ase toothpaste $3.36 \mathrm{~g} /$ day $\times$ residual index 0.05 (101).

bUse mouthwash $50 \mathrm{~g} /$ day $\times$ residual index 0.1 (User's manual, 8). 
SED (mg/kg/day): Systemic Exposure Dosage

A (g/day): Amount of cosmetics used daily

C (\%): Maximum allowable concentration of cosmetic ingredient

DAp (\%): Dermal absorption rate of cosmetic ingredient $60 \mathrm{~kg}$ : Average body weight

The oral SED for oral care products was calculated using a $100 \%$ absorption rate and residual indices of 0.05 (toothpaste) and 0.1 (mouthwash). Table 10 shows the SED of TCS.

\section{RISK CHARACTERIZATION}

To evaluate the safe concentration of TCS in cosmetics, the margin of safety (MOS) is estimated using NOAEL and SED. When the MOS is over 100, it is considered to be safe.

The MOS was determined to be 84 when it was assumed that representative type cosmetic and toothpaste containing $0.3 \%$ TCS and mouthwash containing $0.02 \%$ were used in parallel. Under the assumption that rinse-off body cleansing products (shower gel, hand washing soap), deodorants, color cosmetic products (excluding children and lip products) and oral care products containing $0.3 \%$ TCS were used in parallel, the margin of safety was 253.5 (Table 11). Therefore, MOS indicated that representative type cosmetics, toothpaste, and mouthwash containing TCS is not safe. Although the exposure scenario of combined use of representative type cosmetic and toothpaste containing $0.3 \%$ TCS and mouthwash containing $0.02 \%$ is very conservative, MOS of 84 suggests regulatory plan to reduce exposure of TCS.

\section{SUMMARY AND CONCLUSION}

TCS is an antimicrobial compound that has been used in consumer products for about 40 years. TCS is a chlorinated aromatic compound with phenol and ether functional groups. TCS did not induce acute toxicity via oral administration, and SCCS suggested a NOAEL of $12 \mathrm{mg} /$ $\mathrm{kg}$ bw/day based on observed chronic haematoxicity and reduced spleen weight in rats (3). Topically administered TCS caused mild irritation in animal studies (3,28-30, $36,44-49,51)$. No reproductive or developmental toxicity was observed in response to TCS. In all studies, maternal toxicity was observed, indicating that a sufficiently high dose of TCS was tested. Some toxicity, such as fetal weight loss, was also observed as an indirect consequence of maternal toxicity $(2,3,36,65-73)$. In addition, in vitro and in vivo testing of TCS showed no potential for genotoxicity $(3,74-81,83-86)$. TCS did not cause phototoxicity or neurotoxicity $(3,88)$. In the current study, a NOAEL of $12 \mathrm{mg} / \mathrm{kg}$ bw/day was determined for TCS according to the Scientific Committee on Consumer Safety (SCCS) proposal. Also, in order to calculate SED, percutaneous absorption was assumed to be $14 \%$, which is the highest result observed in human in vivo skin uptake studies $(36,94)$.

According to possible conservative scenarios, SED was estimated to $0.14337 \mathrm{mg} / \mathrm{kg}$ bw/day for combined use of representative type cosmetics and oral care products (toothpaste and mouthwash) and $0.04733 \mathrm{mg} / \mathrm{kg}$ bw/day for combined use of rinse-off products (cleansing products), deodorants, color cosmetic products, and oral care products (toothpaste and mouthwash). These SEDs were calculated based on Korean cosmetics usage. The MOS of TCS was 84 for combined use of representative type cosmetics and oral care products (toothpaste and mouthwash) and 253.5 for combined use of rinse-off products (cleansing products), deodorants, color cosmetic products, and oral care products (toothpaste and mouthwash). The MOSs of TCS indicated that exposure to TCS may be a concern in combined use of representative type cosmetics and oral care products (toothpaste and mouthwash), but not for combined use of rinse-off products (cleansing products), deodorants, color cosmetic products, and oral care products (toothpaste and mouthwash). Based on this risk assessment, the MFDS revised the regulation of cosmetics from representative cosmetics containing $0.3 \%$ of TCS to rinseoff products (cleansing products), deodorants, and color

Table 11. Risk characterization

\begin{tabular}{|c|c|c|c|c|c|}
\hline Products & Triclosan concentration $(\%$ & & $\begin{array}{c}\text { SED } \\
(\mathrm{mg} / \mathrm{kg} \mathrm{bw} / \text { day })\end{array}$ & $\begin{array}{c}\text { NOAEL } \\
\text { (mg/kg bw/day) }\end{array}$ & $\operatorname{MOS}^{\mathrm{a}}$ \\
\hline \multirow{3}{*}{$\begin{array}{l}\text { Representative type cosmetics }+ \\
\text { Toothpaste }+ \text { Mouthwash }\end{array}$} & Representative type cosmetics & 0.3 & \multirow{3}{*}{0.143367} & \multirow{3}{*}{12} & \multirow{3}{*}{83.7} \\
\hline & Toothpaste & 0.3 & & & \\
\hline & Mouthwash & 0.02 & & & \\
\hline \multirow{3}{*}{$\begin{array}{l}\text { Rinse-off body cleaning products }+ \text { deodorant }+ \\
\text { color cosmetic products (except for eye and } \\
\text { lip products })+ \text { Toothpaste }+ \text { Mouthwash }\end{array}$} & Cosmetics & 0.3 & \multirow{3}{*}{0.04733} & \multirow{3}{*}{12} & \multirow{3}{*}{253.5} \\
\hline & Toothpaste & 0.3 & & & \\
\hline & Mouthwash & 0.02 & & & \\
\hline
\end{tabular}

${ }^{a} \mathrm{MOS}=\mathrm{NOAEL} \div \mathrm{SED} \geq 100$ : acceptable risk. 
cosmetic products containing $0.3 \%$ of TCS in 2015. At present, TCS may be safely used as a preservative in cosmetics and may not threaten the comnsumer's health. If new toxicological data are obtained in the future, the risk assessment should be performed to update the regulation appropriately.

\section{ACKNOWLEDGMENTS}

This work was supported by grants (14172MFDS975 and 19172MFDS221) from the Ministry of Food and Drug Safety, Korea in 2014 and 2019.

\section{CONFLICT OF INTEREST}

The authors declare that they have no conflicts of interest.

Received February 21, 2019; Revised March 8, 2019; Accepted March 10, 2019

\section{REFERENCES}

1. US FDA (Food and Drug Administration) (2008) National Toxicology Program, Department of Health and Human Services, Nomination Profile, Triclosan [CAS3380-34-5], Supporting Information for Toxicological Evaluation Toxicology Program.

2. CIR (Cosmetic Ingredient Review) (2010) Final Report Triclosan. Available from: http://www.cir-safety.org/sites/default/ files/FR569.pdf/.

3. SCCP (Scientific Committee on Consumer Products) (2009) OPINION ON Triclosan COLIPA n ${ }^{\circ}$ P32. Available from: http://ec.europa.eu/health/ph_risk/committees/04_sccp/docs/ sccp_o_166.pdf/.

4. Dayan, A.D. (2007) Risk assessment of triclosan [Irgasan] in human breast milk. Food Chem. Toxicol., 45, 125-129.

5. Wolff, M., Teitelbaum, S., Windham, G., Pinney, S., Britton, J., Chelimo, C., Godbold, J., Biro, F., Kushi, L., Pfeiffer, C. and Calafat, A. (2007) Pilot study of urinary biomarkers of phytoestrogens, phthalates, and phenols in girls. Environ. Health Perspect., 115, 116-121.

6. Calafat, A.M., Ye, X., Wong, L.Y., Reidy, J.A. and Needham, L.L. (2008) Urinary concentrations of triclosan in the U.S. population: 2003-2004. Environ. Health Perspect., 116, 303-307.

7. Cullinan, M.P., Palmer, J.E., Carle, A.D., West, M.J., Westerman, B. and Seymour, G.J. (2015) The influence of a triclosan toothpaste on adverse events in patients with cardiovascular disease over 5-years. Sci. Total Environ., 508, 546-552.

8. SCCS (Scientific Committee on Consumer Safety) (2011) Opinion On Triclosan, SCCS/1414/11.

9. van Dijk, A. (1994) 14C-Triclosan: Absorption, Distribution Metabolism and Elimination after Single/Repeated Oral and Intravenous Administration to Hamsters (RCC Project 351707), RCC Umweltchemie AG, Itingen/BL, Switzerland.

10. van Dijk, A. (1995) 14C-Triclosan: Absorption, Distribu- tion, Metabolism and Elimination after Single/Repeated Oral and Intravenous Administration to Mice (RCC project no. 337781), RCC Umweltchemie AG, Itingen/BL, Switzerland.

11. van Dijk, A. (1996) 14C-Triclosan: Absorption, Distribution and Excretion (ADE) after Single Oral and Repeated Oral Administration to Male Rats (RCC Project 341998), RCC Umweltchemie AG, Itingen/BL, Switzerland.

12. Lin, Y.J. and Smith, N.L. (1990) Pharmacokinetics of Triclosan in Rats Following a Single Oral Administration, Colgate-Palmolive Company, Piscataway, New Jersey.

13. Park, M., Kim, S., Kim, Y., Nam, D.J., Ryoo, J.H. and Lim, S. (2019) Relationship between personal care products usage and triclosan exposure: the second Korean National Environmental Health Survey (KoNEHS 2012-2014). Ann. Occup. Environ. Med., 31, 2.

14. Crofton, K.M., Paul, K.B., Devito, M.J. and Hedge, J.M. (2007) Short-term in vivo exposure to the water contaminant triclosan: evidence for disruption of thyroxine. Environ. Toxicol. Pharmacol., 24, 194-197.

15. Paul, K.B., Hedge, J.M., Bansal, R., Zoeller, R.T., Peter, R., DeVito, M.J. and Crofton, K.M. (2012) Developmental triclosan exposure decreases maternal, fetal, and early neonatal thyroxine: a dynamic and kinetic evaluation of a putative mode-of-action. Toxicology, 300, 31-45.

16. Paul, K.B., Thompson, J.T., Simmons, S.O., Vanden Heuvel, J.P. and Crofton, K.M. (2013) Evidence for triclosaninduced activation of human and rodent xenobiotic nuclear receptors. Toxicol. In Vitro, 27, 2049-2060.

17. Veldhoen, N., Skirrow, R.C., Osachoff, H., Wigmore, H., Clapson, D.J., Gunderson, M.P., Van Aggelen, G. and Helbing, C.C. (2006) The bactericidal agent triclosan modulates thyroid hormone-associated gene expression and disrupts postembryonic anuran development. Aquat. Toxicol., 80, 217-227.

18. Axelstad, M., Boberg, J., Vinggaard, A.M., Christiansen, S. and Hass, U. (2013) Triclosan exposure reduces thyroxine levels in pregnant and lactating rat dams and in directly exposed offspring. Food Chem. Toxicol., 59, 534-540.

19. Yueh, M.F. and Tukey, R.H. (2016) Triclosan: A widespread environmental toxicant with many biological effects. Annu. Rev. Pharmacol. Toxicol., 56, 251-272.

20. Health Canada (Environment and Climate Change Canada Health Canada) (2016) Assessment Report Triclosan, Chemical Abstracts Service Registry Number 3380-34-5. Available from: http://www.ec.gc.ca/ese-ees/65584A12-2B7D-42739F7A-38EDF916ECAF/EN\%20FSAR\%20Triclosan\%20with\% 20ISBN.pdf/.

21. Ley, C., Pischel, L. and Parsonnet, J. (2017) Triclosan and triclocarban exposure and thyroid function during pregnancy-a randomized intervention. Reprod. Toxicol., 74, 143149.

22. Rodricks, J.V., Swenberg, J.A., Borzelleca, J.F., Maronpot, R.R. and Shipp, A.M. (2010) Triclosan: a critical review of the experimental data and development of margins of safety for consumer products. Crit. Rev. Toxicol., 40, 422-484.

23. MFDS (The Ministry of Food and Drug Safety) (2017) Guideline for Risk Assessment of Cosmetic. Available from: http://www.nifds.go.kr/_custom/nifds/_common/board/download. jsp?attach_no $=22848 /$. 
24. SCF (Scientific Committee on Food) (2000) Opinion of the Scientific Committee on Food on the 10th Additional List of Monomers and Additives for Food Contact Materials [adopted by the SCF on 2000 Jun 22]. Available from: http:// europa.eu.int/comm/food/fs/sc/scf/out62_en.pdf/.

25. EFSA (European Food Safety Authority) (2004) Opinion of the Scientific Panel on food additives, flavourings, processing aids and materials in contact with food. EFSA Journal, 37, 1-7.

26. MFDS (The Ministry of Food and Drug Safety) (2017) Cosmetics Research Team, Risk Assessment of Cosmetics, Cheongju-Si: The National Institute of Food and Drug Safety Evaluation, pp. 151-172.

27. ECHA (European Chemical Agency) (2019) Toxicological Information (Triclosan). Available from: https://echa.europa. eu/registration-dossier/-/registered-dossier/12675/1/.

28. Burns, J. (1996) 14-Day Repeated Dose Dermal Study of Tricolsan in Mice. Triclosan Industry Alliance, Corning Hazleton Incorporated Laboratory. CHV 6718-101.

29. Burns, J. (1997) 14-Day Repeated Dose Dermal Study of Tricolsan in CD-1 Mice, Triclosan Industry Alliance, Corning Hazleton Incorporated Laboratory.

30. Burns, J. (1997) 14-Day Repeated Dose Dermal Study of Tricolsan in CD-1 Mice, Triclosan Industry Alliance, Corning Hazleton Incorporated Laboratory, CHV 6718-102. CHV 2763-100.

31. Leutkemeier, H., Ullmann, L., Zak, F., Sachsse, K. and Shess, R. (1974) Irgasan DP 300 (Fat 80023/A) 21-Day Inhalation Study on the Rat. Ciba-Geigy Limited.

32. Thevenaz, P. (1987) 28-Day Toxicity Studying Mice (Administration in Feed) with Special Reference To Histopathology, Final Report, Cibe-Geigy Limited. GU project number 864005.

33. Trutter, J.A. (1993) 13-Week Subchronic Oral Toxicity Study of Triclosan in CD-1 Mice, HWA 483-287, Hazleton Washington Inc., Report No. CB 93/40.

34. Litton Bionetics Inc. (1983) 90-Day Oral Toxicity Study in Rats with Fat 80-023/H (Litton Bionetics Inc.) Final Report, LBI Project No. 22188.

35. NICNAS (National Industrial Chemicals Notification And Assessment Scheme) (2009) Priority Existing Chemical Assessment Report No. 30. Triclosan. Available from: http:// www.nicnas.gov.au/_data/assets/pdf_file/0017/4391/PEC_ 30_Triclosan_Full_Report_PDF.pdf/.

36. Schmid, H., Dotti, A., Keller, B., Kouchakji, G., Luetkemeir, H., Wilson, J., Biedermann, K. and Marbot, H. (1994) 13-Week Toxicity Study with Fat $80^{\prime} 023 / \mathrm{R}$ in the Hamster, Final Report, Ciba-Geigy Limited, RCC Project Number 356490.

37. Leuschner, F., Leuschner, A., Schwerdtfeger, W. and Dontenwill, W. (1970) 90 Days Oral Toxicity Study in Beagle Dogs with $\mathrm{CH}$ 3565, Labortorium fur Pharmakologie und Toxikologie.

38. Paterson, R.A. (1969) 13-Week Oral Toxicity Study in Rabbits. Irgasan DP 300, GP 41 353, Ciba-Geigy UK, Stamford Lodge, Wilmslow.

39. Noel, P.R.B., Mawdesley-Thomas, L.E., Squires, P.F. and Street, A.E. (1969) Oral Toxicity Study in Baboons, Repeated Dosage for 4 and 13 Weeks. Irgasan DP 300, GP 41353, Huntingdon Research Centre, UK.
40. Drake, J. (1975) 1 Year Oral Toxicity Study in Baboons with Compound Fat 80 023/A, Ciba-Geigy Limited, Jul 26.

41. Auletta, C. (1995) An 18-Month Oral Oncogenicity study of Tricolsan in the Mouse via Dietary Administration, Pharmaco LSR, Study No. 93-2260.

42. Yau, E. and Green, J. (1986) Fat 80'023 2-Year Oral Administration to Rats (MIN 833005), Ciba-Geigy Limited, Apr 28.

43. Chambers, P. (1999) FAT 80'023/S Potential Tumorigenic and Chronic Toxicity Effects in Prolonged Dietary Administration to Hamsters, Huntingdon Life Sciences Ltd.

44. Ena, L., Lim, J.S., Son, J.Y., Park, Y.J., Lee, Y.H., Kim, J.Y., Kwack, S.J., Lee, B.M., Ahn, M.Y. and Kim, H.S. (2018) Evaluation of subchronic exposure to triclosan on hepatorenal and reproductive toxicities in prepubertal male rats. $J$. Toxicol. Environ. Health A, 81, 421-431.

45. Barkvoll, P. and Rølla, G. (1994) Triclosan protects the skin against dermatitis caused by sodium lauryl sulphate exposure. J. Clin. Periodontol., 21, 717-719.

46. Bendig, J.W. (1990) Surgical hand disinfection: comparison of $4 \%$ chlorhexidine detergent solution and $2 \%$ triclosan detergent solution. J. Hosp. Infect., 15, 143-148.

47. Skaare, A., Kjaerheim, V., Barkvoll, P. and Rolla, G. (1997) Skin reactions and irritation potential of four commercial toothpastes. Acta. Odontol. Scand., 55, 133-136.

48. Skaare, A.B., Rölla, G. and Barkvoll, P. (1997) The influence of triclosan, zinc or propylene glycol on oral mucosa exposed to sodium lauryl sulphate. Eur. J. Oral. Sci., 105, 527-533.

49. Sachsse, K. and Ullmann, L. (1975) Skin Irritation in the Rabbit after Single Application of FAT 80'023/A. Tox./ Pathology PH 2.63, Project Siss 4719, Ciba-Geigy Ltd, CHBasel.

50. Trimmer, G. (1994) 90-Day Subchronic Dermal Toxicity Study in the Rat with Satellite Group with Irgasan DP300 (MRD-92-399), Ciba-Geigy Limited, Exxon Biomedical Sciences, Inc, Toxicology Laboratory. Laboratory Project ID 139910B.

51. Dorner, R.L. (1973) The Systemic Toxicological Effects of Three Bacteriostats Topically Applied to the Skin of Young Canines, L.R. E. Study \# 301-002. Laboratory Research Enterprises, Inc., Kalamazoo, Michigan.

52. Hazleton Labs, Inc. (1979) 90 Day Bathing of Newborn Rhesus Monkeys with Triclosan Soap Solution. Hazleton Laboratories America Inc., Vienna, Virginia.

53. Baert, J.H., Veys, R.J., Ampe, K. and De Boever, J.A. (1996) The effect of sodium lauryl sulphate and triclosan on hamster cheek pouch mucosa. Int. J. Exp. Pathol., 77, 73-78.

54. Ullmann, L. (1980) Report on Eye Irritation in the Rabbit after Single Application of FAT 80'023/A, Final Report Project no. 801012, Experimental Toxicology, Ciba-Geigy Limited, Basle, Switzerland. Jul 8.

55. Lyman, F.L. and Furia, T.E. (1968) Toxicology of 2,4,4'-trichloro-2'-hydroxyphenyl ether. IMS. Ind. Med. Surg., 37, 546.

56. DeSalva, S.J., Kong, B.M. and Lin, Y.J. (1989) Triclosan: a safety profile. Am. J. Dent., 185-196.

57. Mitchell, J.C., Adams, R.M., Glendenning, W.E., Fisher, A., Kanof, N., Larsen, W., Maibach, H.I., Rudner, E.J., Schnorr, W., Storrs, F. and Taylor, J.S. (1982) Results of standard patch 
tests with substances abandoned. Contact Derm., 8, 336-337.

58. Perrenoud, D., Bircher, A., Hunziker, T., Suter, H., BrucknerTuderman, L., Stäger, J., Thürlimann, W., Schmid, P., Suard, A. and Hunziker, N. (1994) Frequency of sensitization to 13 common preservatives in Switzerland. Swiss Contact Dermatitis Research Group. Contact Derm., 30, 276-279.

59. Schnuch, A., Geier, J., Uter, W. and Frosch, P.J. (1998) Patch testing with preservatives, antimicrobials and industrial biocides. Results from a multicentre study. Br. J. Dermatol., 138, 467-476.

60. Savage, L., Rose, R. and Wilkinson, M. (2011) Airborne contact dermatitis to triclosan. Contact Derm., 65, 239-240.

61. Toxicological Resources (1974) Guinea Pig Buehler Dermal Sensitisation Study, Compound 1291, Project No. 2118-74, Toxicological Resources.

62. Lachapelle, J.M. and Tennstedt, D. (1979) Low allergenicity of triclosan. Predictive testing in guinea pigs and in humans. Dermatologica, 158, 379-383.

63. Maurer, T., Thomann, P., Weirich, E.G. and Hess, R. (1979) Predictive evaluation in animals of the contact allergenic potential of medically important substances. II. Comparison of different methods of cutaneous sensitization with "weak" allergens. Contact Derm., 5, 1-10.

64. Wnorowski, G. (1994) Dermal Sensitisation Test - Buehler Method for Triclosan. Project Number 2635, Product Safety Labs, New Jersey.

65. Morseth, S.L. (1988) Two-Generation Reproduction Study in Rats Fat $80^{\prime} 023$ A. Ciba-Geigy Corporation, Hazleton Laboratories America, Inc., HLA Study No. 2386-100.

66. Denning, H., Sliva, S. and Wilson, G. (1992) Triclosan: Effects on Pregnancy and Post Natal Development in Rats, Environmental Safety Laboratory, Unilever Research, Document Reference 92-105.

67. Rodríguez, P.E. and Sanchez, M.S. (2010) Maternal exposure to triclosan impairs thyroid homeostasis and female pubertal development in Wistar rat offspring. J. Toxicol. Environ. Health A, 73, 1678-1688.

68. Kumar, V., Balomajumder, C. and Roy, P. (2008) Disruption of LH-induced testosterone biosynthesis in testicular Leydig cells by triclosan: probable mechanism of action. Toxicology, 250, 124-131.

69. Kumar, V., Chakraborty, A., Kural, M.R. and Roy, P. (2009) Alteration of testicular steroidogenesis and histopathology of reproductive system in male rats treated with triclosan. Reprod. Toxicol., 27, 177-185.

70. Stoker, T.E., Gibson, E.K. and Zorrilla, L.M. (2010) Triclosan exposure modulates estrogen-dependent responses in the female wistar rat. Toxicol. Sci., 117, 45-53.

71. Sandborgh-Englund, G., Adolfsson-Erici, M., Odham, G. and Ekstrand, J. (2006) Pharmacokinetics of triclosan following oral ingestion in humans. J. Toxicol. Environ. Health A., 69, 1861-1873.

72. Wu, J., Yue, H. and Cai, Z. (2009) Investigation on metabolism and pharmacokinetics of triclosan in rat plasma by using UPLC-triple quadrupole MS. Se Pu, 27, 724-730.

73. Christian. M. and Hoberman, A. (1992) Developmental Toxicity (Embryo-Fetal Toxicity and Teratogenic Potential) Study of C-P Sample No. 38326 Administered Orally Via the Diet to Cr1: CD1(ICR) BR Presumed Pregnant Mice.
Argus Research Laboratories. Protocol number 403-010. Sponsor's Study number 92-001.

74. Biodynamics Inc. (1992) A Range-Finding Study to Evaluate the Toxicity of Irgacare MP (C-P sample No: 8328) in the Pregnant Rat. Unpublished final test report 91-3654, ColgatePalmolive study 91-013. Biodynamics Inc., New Jersey.

75. Schroeder, R. and Daly, I. (1992) A Segment II Teratology Study in Rabbits with Irgacare MP (C-P sample no. 38328) Bio/Dynamics. Project no. 91-3666, Colgate-Palmolive study no. 91-006, Apr 16.

76. Schroeder, R. and Daly, I. (1992) A Segment II Teratology Study in Rats with Irgacare MP (C-P Sample No. 38328) Bio/Dynamics. Project No. 91-3665, Colgate-Palmolive Study No. 91-005, Apr 16.

77. Arni, P. and Müller, D. (1979) Intrasanguine Host-Mediated Assay with S. Typhimurium with FAT 80 023/A (Experiment no. 78/2803), Ciba-Geigy Ltd., Basel.

78. Henderson, L.M., Proudlock, R.J., Haynes, P. and Meaking, K. (1988) Triclosan Mouse Micronucleus Test (HRC Study No. ULR 213/88492, Unilever Study No. KC 880168), Huntingdon Research Centre Ltd., Huntingdon.

79. Riach, C.G. (1988) Triclosan: Assessment of Genotoxicity in an Unscheduled DNA Synthesis Assay Using Adult Rat Hepatatocyte Primary Cultures (IRI Report no. 4667, IRI Project no. 738388, Unilever Study No. KU 880258), Inveresk Research International, Musselburgh.

80. Brooker, P.C., Gray, V.M. and Howell, A. (1988) Triclosan, Analysis of Metaphase Chromosomes Obtained from CHO Cells Cultured in Vitro (ULR 214/88731, Unilever Test No. KC 880171), Huntingdon Research Centre, Huntingdon.

81. CCR Cytotest Cell Research (1991) Chromosome Aberration Assay in Bone Marrow Cells of the Rat wit FAT 80'023/Q (CCR Project No. 218305), CCR Cytotest Cell Research GMBH \& Co., Roßdorf.

82. Strasser, F.F. and Müller, D. (1978) Point Mutation Assay with Mouse Lymphoma Cells I. In vitro test II. Host-mediated assay (Experiment No. 782305), Ciba-Geigy Ltd., CH-Basel.

83. Russell, L.B. and Montgomery, C.S. (1980) Use of the mouse spot test to investigate the mutagenic potential of triclosan (Irgasan DP300). Mutat. Res., 79, 7-12.

84. Strasser, F.F. and Müller, D. (1973) Chromosome Studies on Somatic Cells--GP 41353 (Triclosan), Chinese Hamster, Ciba-Geigy Ltd., Basel.

85. Langauer, M. and Müller, D. (1974) Nucleus Anomaly Test on Somatic Interphase Nuclei, GP 41343 (Triclosan), Chinese Hamster. Ciba-Geigy Ltd., Basel.

86. Magnusson, J. (1979) Mutagenic Effects of "Irgasan" on Drosophila Melanogaster (Brief report), Wallenberg Laboratory, Stockholm.

87. Fritz, H. (1971) Dominant Lethal Study (Experiment No. 32710200), Ciba-Geigy Ltd, Basel.

88. Hool, G., Strasser, F.F. and Müller, D. (1978) Chromosome Studies in Male Germinal Epithelium, FAT 80 023/A, Mouse (Experiment no. 78-2903), Ciba-Geigy Ltd., CH-Basel.

89. ECHA (European Chemical Agency) (2019) Carcinogenicity (triclosan). Available from: https://echa.europa.eu/registration-dossier/-/registered-dossier/12675/7/8/?documentUUID= 7f7a0e59-5295-4cfa-b2e2-d167a4fc2d8c/.

90. Urbach, F. (1973) Phototoxicity Study in Mice, Pigs, and 
Humans, Irgasan DP-300, Temple University Skin and Cancer Hospital, Philadelphia, Apr 4.

91. Bagley, D.M. and Lin, Y.J. (2000) Clinical evidence for the lack of triclosan accumulation from daily use in dentifrices. Am. J. Dent., 13, 148-152.

92. Weatherly, L.M. and Gosse, J.A. (2017) Triclosan exposure, transformation, and human health effects. J. Toxicol. Environ. Health B. Crit Rev., 20, 447-469.

93. US EPA (Environmental Protection Agency) (2008) Office of Prevention, Pesticides and Toxic Substances, Reregistration eligibility decision (RED) for Triclosan, List B, Case 2340.

94. Black, J.G. and Howes, D. (1975) Percutaneous absorption of triclosan from toilet preparations. J. Soc. Cosmet. Chem., 26, 205-215.

95. Chun Hong, H.S., Kurz, N.D., Wolf, T. and De Salva, S.J. (1976) Chemical Analysis of Hexachlorophene (HCP), Tribromsalan (TBS), Triclosan (DP-300), Triclocarban (TCC) and Cloflucarban (CF3) in Tissues, Blood and Urine of Animals and Humans, Meeting of the Society of Toxicology in Atlanta, Georgia.

96. Moss, T., Howes, D. and Williams, F.M. (2000) Percutaneous penetration and dermal metabolism of triclosan $(2,4,4$ 'Trichloro-2 hydroxydiphenyl Ether) Food Chem. Toxicol., 38, 316-370.
97. EC (European Commission) (2003) Technical Guidance Document on Risk Assessment in Support of Commission Directive 93/67/EEC on Risk Assessment for New Notified Substances, Commission Regulation (EC) No 1488/94 on Risk Assessment for Existing Substances, Directive 98/ 8/EC of the European Parliament and of the Council concerning the Placing of Biocidal Products on the Market. Part 1. Luxembourg, Office for Official Publications of the European Communities.

98. Park, G.H., Nam, C., Hong, S., Park, B., Kim, H., Lee, T., Kim, K., Lee, J.H. and Kim, M.H. (2018) Socioeconomic factors influencing cosmetic usage patterns. J. Expo. Sci. Environ. Epidemiol., 28, 242-250.

99. Thompson, T.A., Borman, C.H. and Goodblatt, R.S. (1975) Triclosan (Report 2): Concentration in Human Plasma and Urinary Excretion after Dermal Application of GP 41353 Patient Skin Prep, Drug Metabolism Report 1975-18.

100. Stierlin, H. and Mucke, W. (1976) GP 41 353: Investigations of Percutaneous Absorption in the Rat and the Rabbit. Ciba-Geigy Limited.

101. Park, I.S. and Lee, S.H. (2010) A study on the amount of toothpaste used among some college students. JKSDH, 10, 577-584. 